\title{
THE ROLE OF GOVERNMENT IN ANTI-SOCIAL REDISTRIBUTIVE ACTIVITIES
}

\author{
KONSTANTINOS ANGELOPOULOS \\ APOSTOLIS PHILIPPOPOULOS
}

CESIFO WORKING PAPER NO. 1427

CATEgORY 5: Fiscal Policy, Macroeconomics AND Growth MARCH 2005 


\title{
THE ROLE OF GOVERNMENT IN ANTI-SOCIAL REDISTRIBUTIVE ACTIVITIES
}

\begin{abstract}
It is known that anti-social redistributive activities (rent seeking, tax evasion, corruption, violation of property rights, delay of socially beneficial reforms, etc) hurt the macroeconomy. But it is less known what is the role of government size as a determinant of such activities. We use data from 64 counties (both developed and developing) in 5-year periods over 19802000. As a measure of anti-social activities, we use the ICRG index; as a measure of government size, we use the government share in GDP; and as a measure of government efficiency, we construct an index by following the methodology of Afonso, Schuknecht and Tanzi (2003). Our regressions show that what really matters to social incentives is the relation between size and efficiency. Specifically, while a larger size of government is bad for incentives when one ignores efficiency, the results change drastically when government efficiency is also taken into account. Only when our measure of size exceeds our measure of efficiency, larger public sectors are bad for incentives. By contrast, when efficiency exceeds size, larger public sectors are not bad; actually, in the case where efficiency is measured by government performance in the policy areas of administration, stabilization and infrastructure, larger public sectors significantly improve incentives.
\end{abstract}

JEL Code: H3, H11, D7.

Keywords: government and behaviour of agents, collective decision-making.

\author{
Konstantinos Angelopoulos \\ Department of International and \\ European Economic Studies \\ Athens University of Economics \& Business \\ 76 Patission street \\ 10434 Athens \\ Greece \\ conangel@aueb.gr
}

\author{
Apostolis Philippopoulos \\ Department of Economics \\ Athens University of Economics \& Business \\ 76 Patission street \\ 10434 Athens \\ Greece \\ aphil@aueb.gr
}

The research reported here draws on recent collaboration with Makis Tsionas; we are grateful to him. We also thank Harris Dellas, George Economides, Sarantis Kalyvitis, Jim Malley, Theodore Palyvos, Hyun Park and Vangelis Vassilatos for discussions. All remaining errors are ours. The first co-author is grateful to the "Foundation Propondis" for their support; he also acknowledges financial support from the Greek Ministry of Education and the EU under the "Iraklitos" research fellowship program. 


\section{Introduction}

Incentives motivate economic and social life. For many economists, economics is to a large extent a matter of "good" incentives. ${ }^{1}$ In this paper, by good incentives we mean the involvement in socially productive activities as opposed to socially unproductive activities, legal or illegal, that aim at a redistributive struggle for a larger share of the national pie. In other words, by socially unproductive, or anti-social, activities we mean situations in which economic agents (e.g. social groups, professional associations, public sector unions, industrial associations, networks, or even single individuals) use their private time and resources to gain an advantage in dividing up the benefits of aggregate economic activity and appropriate other agents' product and effort. $^{2}$

In their search for private gain, anti-social agents reduce the pie that initiated the redistributive struggle in the first place. For instance, Olson (1982) argues that entrenched vested interests are a main cause for economic decline, while Rodrik (1999) points out that domestic social conflicts and redistributive struggles play a key role in understanding why growth rates lack persistence and why some countries have experienced a sharp decline in growth since the mid 1970s. In the end, even aggressive agents, that look as winners, may lose by finding themselves with a larger slice of a smaller pie.

Anti-social redistributive activities (ASRA) can take a variety of forms. ${ }^{3}$ For instance, they can take the form of rent-seeking competition for extra favors from the state, which benefit specific groups at the expense of others ${ }^{4}$ (see e.g. Persson and Tabellini (2000, chapter 7), Mohtadi and Roe (1998, 2003), Alesina (1999), Mauro (2002) and Park et al. (2003)). Or they can take the form of a distributive struggle

\footnotetext{
${ }^{1}$ See e.g. the examples in the book by Laffont and Martimort (2002).

${ }^{2}$ See Mueller (2003, chapters 3 and 29) for a survey of the literature on redistribution. Here, we focus on what Mueller calls "involuntary" redistribution, or "redistribution as taking".

${ }^{3}$ Although different authors use different terms, they describe similar problems and use similar proxies. For instance, Knack and Keefer (1995) use the term "institutions", Barro (1997) uses the term "rule of law", Knack and Keefer (1997) use the term "social capital", Hall and Jones (1999) use the term "social infrastructure", and Zak and Knack (2001) use the term "trust"; on the other side of the coin, Rodrik (1999) uses the term "social conflict". In this paper, we prefer to use the term "ASRA". Note also that we will use the terms incentives, behavior and activities interchangeably.

${ }^{4}$ Rent seeking is the socially costly pursuit of a contestable prize, where the prize can take various forms (for surveys of rent seeking, see e.g. Drazen, 2000, chapters 8 and 10, and Mueller, 2003, chapter 15). Usually it is the government that can create, increase and protect a rent. As a result, and due to the post-war expansion of government, fiscal rent seeking is a key way of redistributive politics. In this case, examples of rent seeking include lobbying for the provision of local public goods, obtaining contracts for the provision of public goods, securing public sector employment, getting extra fiscal transfers and tax exemptions, using the revenue from privatised public assets for the benefit of special interests like public sector unions, etc. This goes back to Tullock (1967) and Krueger (1974).
} 
among power groups, like trade unions and high executives (see e.g. Mueller (2003, chapter 20) for interest groups). Or they can take the form of non-adoption, delay or reversal of socially beneficial reforms and policy changes as vested interests preserve the status quo to keep extra rents (see e.g. Alesina and Drazen (1991) and Drazen (2000, chapter 10)). Or they can take the form of extraction from national natural resources for private benefit (see e.g. Leite and Weidmann (2002) and Grossman and Mendoza (2003)). Or, when there are trade impediments, they can take the form of higher prices as firms charge higher prices to increase their profit margins. Or they can take the form of shadow or underground economic activities (see e.g. Schneider and Enste (2000)). But ASRA can also take the form of illegal activities like tax evasion, corruption, criminal violations of property rights, smuggling or fraud (see e.g. Rose-Ackerman (1999) and Mueller (2003, chapter 16)). Finally, they can take the form of anti-social behavior in the form of incivility, disorder, nuisance and disrespect for public goods (see e.g. The Economist, September $13^{\text {th }} 2003$, p. 36).

ASRA are at best a zero-sum game. As Mueller (2003, p. 9) puts it, "if stealing, and guarding against it, detract A and B's ability to produce corn and cattle, it becomes a negative-sum game". Nevertheless, although such activities lead to socially inefficient outcomes, they can be privately rational. Utility-maximizing agents tradeoff personal benefits and costs expected from alternative uses of their time and resources. ${ }^{5}$ In a decentralized (Nash) equilibrium, they may find it optimal to allocate a part of their time and resources to ASRA. However, the society would be better off (the national pie would be larger), if economic agents allocated their resources to socially productive activities. A larger national pie could in turn allow higher personal welfare. Thus, in most cases, there is a prisoners' dilemma situation in the sense that everybody gets worse off.

But, although the human motivator is utility maximization (namely, self interest) in all societies, societies do differ in the way they channel self-interest. As Rose-Ackerman (1999, p. 2) points out, in some societies, self-interest is transmuted mainly into socially productive activities that lead to an efficient allocation of resources. In some other societies, by contrast, self-interest is transmuted mainly into socially unproductive activities that lead to an inefficient allocation of resources.

This non-technical paper investigates the determinants of ASRA. Obviously, many factors can contribute to such activities ranging from fundamentals to incentive

\footnotetext{
5 Concerning the private costs of ASRA, lobbying, participating in strikes, paying campaign contributions to politicians, bribing, paying lawyers, hiring private security services, etc, are costly activities. For the social costs of ASRA, see below in Section 3.
} 
schemes and time horizons. Here, the focus will be on the role of the government sector, and in particular on the relation between size and efficiency of the government sector. ${ }^{6}$

There is a popular belief that governments, especially big-sized governments, are a main reason for poor incentives and anti-social redistributive activities. Rent seeking, corruption, tax evasion, moral hazard, etc are believed to be phenomena associated with high government spending, large tax burdens and heavy regulation. For instance, as Mueller (2003, p. 544) puts it, "it is tempting when thinking of this question (why has the underground sector grown so rapidly across all countries?) to seek an answer in the tremendous growth in government that has occurred since 1960". However, Scandinavian countries or Canada have large public sectors, yet they enjoy relatively top institutions and socially behaved citizens. Therefore, as Mueller also warns on the same page "linking up the size and growth of the government sector to the size of growth of the underground economies of the developed countries remains a challenging research task".

We use data from 64 counties (both developed and developing) in 5-year averages over the period 1980-2000. As a measure of ASRA, we will follow usual practice by using the International Country Risk Guide (ICRG) index. As a measure of government size, we will use the government share in GDP. As a measure of government efficiency, we will construct an index by following the methodology of Afonso et al. (2003) for OECD countries. This index measures the efficiency of the public sector of each country in reaching a range of objectives of government intervention. It is calculated as the ratio of performance indicators (output) by a measure of public expenditures related to those indicators (input), based on the assumption that the input is used to achieve that output. Thus, among other things, a contribution of our paper is to rank a relatively large group of countries according to their public sector efficiency, where the latter is measured by government

\footnotetext{
${ }^{6}$ It is important to lay out a conceptual framework that provides the basis of our empirical work. In one-shot non-cooperative games, strategic complementarities can produce multiple, Pareto ranked, Nash equilibria (see e.g. Cooper and John (1988)). By strategic complementarities, we mean that private incentives depend positively on those of the groups we associate with. This implies that, if there are complementarities in anti-social activities (e.g. I tax evade, if the others tax evade), one may get equilibria with good incentives and equilibria with bad incentives depending on fundamentals (see e.g. Tirole (1996)). For instance, in models of rent seeking from state coffers, the probability of an equilibrium with rent seeking increases with the size of public sector and decreases with the degree of efficiency in this sector (see e.g. Mauro (2002) and Park et al. (2003)). This is the conceptual framework here. In turn, the standard results hold. For instance, if an economy is stuck in a bad equilibrium in the one-shot game, a cooperative outcome can be achieved via repetition.
} 
performance in the policy areas of administration, stabilization, infrastructure and education.

Our main empirical findings are as follows. When one ignores efficiency, a larger size of government is bad for incentives. However, the results change drastically when efficiency is also taken into account. Our regressions show that only when our measure of size exceeds our measure of efficiency, larger public sectors are bad for incentives. By contrast, when efficiency exceeds size, larger public sectors are not bad; actually, in the case where efficiency is measured by government performance in the policy areas of administration, stabilization and infrastructure, larger public sectors significantly improve incentives. To give an illustrative example, a large public sector is good for incentives in a country like Canada or Malaysia, in which efficiency is also high. But a public sector of about the same size is bad for incentives in a country like Romania or Uruguay, where efficiency is low.

Therefore, our findings question the popular belief that large sizes per se are bad for incentives. Whether the effect of government size on incentives is positive or negative (or equivalently whether the government size is too small or too large) depends on the nexus between size and efficiency of the public sector. In other words, as it is the case in the literature relating government size to economic growth (see the literature initiated by Barro, 1990), the data reveal an inverted-U relationship between size and incentives. In principle, government intervention can have both positive and negative effects on incentives (see Section 4 below for details), so that countries should be located all along the curve. And this is what the data say.

Our findings are consistent with the warning of Levine and Renelt (1992, p. 951) that "using simple expenditure data without accounting for government efficiency may yield inaccurate measures of the actual delivery of public services". They are also consistent with Tanzi's (1998, p. 566) intuition that "the way the state operates and carries its functions is far more important than the size of public sector activity measured in the traditional way". Mueller (2003, p. 548) also believes that "both the size of government and the quality of its institutions appear to matter".

We will build our arguments in simple logical steps. We begin with measures of social incentives in Section 2. Section 3 reviews how economic performance is shaped by incentives. In Section 4, we search for the determinants of incentives by focusing on government size. A measure of government efficiency is constructed in Section 5. Section 6 presents the main findings by examining the size vis-à-vis efficiency mix. Section 7 concludes. 


\section{Measures of anti-social redistributive activities (ASRA)}

Anti-social redistributive activities (or their mirror image, socially productive activities) are hard to measure. Any empirical methodology can only utilize proxy variables, usually in the form of subjective indexes, which can hopefully provide adequate description of this type of activities. Several indexes have been proposed and used by the literature. In this section, we briefly present the most popular indexes and choose the one we are going to use.

Most studies use the IRIS dataset (version IRIS-3, obtained by countrydata.com) that contains annual values over 1982-1997, as constructed by Stephen Knack and the IRIS Center at the University of Maryland, from monthly ICRG data provided by Political Risk Services. This index includes five sub-indexes: "rule of law", "risk of expropriation", "corruption in government", "risk of repudiation of government contracts" and "quality of bureaucracy". A key advantage of this proxy is that it has a sufficiently long time-series dimension. This dataset has been used by e.g. Knack and Keefer (1995), Barro (1997), Mauro (1998), Rodrik (1999), Hall and Jones (1999), Olson et al. (2000), Persson et al. (2003) and Barro and Sala-i-Martin (2004). Note that some authors use this index as a flow variable (e.g. rent seeking, corruption, social behavior), while some others use it as a stock variable (e.g. quality of government institutions, social infrastructure, social capital). This conforms to our claim above that, at least from an empirical viewpoint, all these different names are effectively picking up the same thing, what we here call ASRA.

There are other datasets available that can also provide proxies for ASRA. For instance, for corruption in government, most researchers use the CPI index as developed by Transparency International. This index has been used by e.g. Treisman (2000), Persson and Tabellini (2003) and Persson et al. (2003). It should be noted that the CPI and the ICRG indexes are highly correlated (see Treisman (2000, p. 411) and Persson et al. (2003, p. 967)). An alternative proxy for corruption, compiled by the organization Business International (BI), has been used by e.g. Mauro (1995) and Ades and Di Tella (1999). The BI index is also highly correlated with the CPI index (see e.g. Treisman (2000, p. 411)). Another measure of socially productive activities can be obtained from the Kaufmann et al. (2003) dataset on governance. This has been used by e.g. Persson and Tabellini (2003) and Persson et al. (2003). This index is also highly correlated with the CPI index (see e.g. Persson and Tabellini (2003, p. 
57)). Finally, Knack and Keefer (1997) and Zak and Knack (2001) have used an index of social capital or trust obtained from the World Values Surveys.

In this paper, we will choose the most commonly used index, the ICRG. Although, like most related indexes, the ICRG index is centred on governance problems, it essentially captures anti-social symptoms in the society as a whole. For instance, corruption of government officials is highly correlated with ASRA in general. To measure ASRA, one could use the "rule of law" sub-index only. However, since there are very strong correlations among the five sub-indexes, we will follow usual practice by using the sum of all five sub-indexes included in the ICRG index.

\section{Anti-social redistributive activities (ASRA) hurt the macroeconomy}

It is recognized that ASRA are associated with worse macroeconomic performance. This section will briefly review the main results and empirical findings of the literature.

ASRA lead to a smaller national pie, so that competing social groups can end up with a larger slice of a smaller pie. The pie gets smaller because national resources are misallocated. ${ }^{7}$ For instance, rent seeking misallocates the talent of people, absorbs labor and so reduces output. Or the tax imposed by the rent-seeking sector on the productive sector can reduce incentives to produce. Or social conflict can discourage innovation. Or low trust environments increase transaction costs and reduce investment. Or collected tax revenues can be used for the benefit of special interests at the expense of public goods and social infrastructure so that the government cannot play its useful Musgravian role.

There is a lot of econometric work confirming that ASRA hurt the macroeconomy. Here we list the most influential empirical papers. Mauro (1995) uses the Business International index of corruption and finds that corruption has a negative effect on growth and private investment. Knack and Keefer (1995) use the ICRG index, as a measure of the quality of institutions, and document a positive effect on growth and private investment in cross-country regressions. The same index has been

\footnotetext{
${ }^{7}$ Theorists have always attributed economic progress to the quality of institutions in a society (see e.g. the early work by Olson (1982) and North (1990)). Recent theoretical work has also shown how noncooperative behavior generates a destructive redistributive struggle over national wealth that leads to poor macro outcomes. See e.g. Benhabib and Rustichini (1996), Lane and Tornell (1996), Mohtadi and Roe (1998, 2003), Tornell and Lane (1999), Mauro (2002), Park and Philippopoulos (2003) and Park et al. (2003); see also Drazen (2000, chapters 10 and 11) for a survey of most of this literature. For surveys of the macro effects of corruption and anti-social activities in general, see e.g. Knack and
} 
repeatedly used in growth regressions (see e.g. Barro (1997) and Barro and Sala-iMartin (2004, chapter 12) who call the index "rule of law") and is always found to be important for growth. Hall and Jones (1999) provide evidence that growth-promoting factors, like physical and human capital formation as well as productivity, are negatively affected by bad social infrastructure as measured by the ICRG index. Rodrik (1999) attributes growth collapses and inability to cope with external shocks to insufficient social infrastructure, which is the result of latent social conflicts and poor governmental institutions with the latter measured by the ICRG index. Olson et al. (2000) also use the ICRG index, as a measure of the quality of governance, to show that it is important in explaining differences in productivity growth among countries. Knack and Keefer (1997) and Zak and Knack (2001) find that social trust is important to growth. There is also a lot of evidence that anti-social activities distort fiscal policy decisions. $^{8}$

We sum up. Social cooperation and cohesion are engines of growth. Since this is already well established in the empirical literature, we do not provide our own evidence (however, results are available upon request).

\section{The fiscal size of government as a determinant of ASRA}

Given the importance of anti-social redistributive activities (ASRA) for macroeconomic outcomes, it is necessary to search for their determinants. The empirical literature has already identified several factors that cause ASRA. ${ }^{9}$ These

Keefer (1997, section II) and Tanzi (1998, pp. 578-586). For intuitive papers on rent seeking and their harmful effects, see Baumol (1990) and Murphy et al. (1991).

${ }^{8}$ ASRA distort the composition of government expenditure and taxation. In particular, Mauro (1998) uses the ICRG index as a proxy for rent seeking and provides evidence that this is resulting in a reallocation of government resources from areas that do not leave much room for extraction (e.g. education) into areas that allow for corruption (e.g. defence) (see also Gupta et al. (2001a, 2001b)). Tanzi and Davoodi (1998) show that high corruption (measured by the ICRG index) is associated with high public investment (because political corruption is often tied to capital projects) but low operation and maintenance expenditure and poor quality of infrastructure. Tanzi and Davoodi (1998) and Ghura (2002) provide evidence that higher corruption is associated with lower tax revenues.

${ }^{9}$ For rich studies see e.g. La Porta et al. (1999), Treisman (2000) and Persson and Tabellini (2003, chapter 3). Commonly proposed determinants of anti-social activities include e.g. ethnic tensions, democracy, openness and inequality. Ethnic tensions result in social conflict and this exacerbates antisocial activities and hurts growth (see e.g. Easterly and Levine (1997), Mauro (1995), La Porta et al. (1999), Persson and Tabellini (2003, chapter 3) and Treisman (2000)). The quality of democracy increases transparency and reduces corruption and illegal activities (see e.g. Treisman (2000), Paldam (2002) and Persson and Tabellini (2003, chapter 3)). Openness has ambiguous effects (see e.g. Tanzi (1998)). On the one hand, it can reduce rent seeking because it removes controls (e.g. tariffs, import quotas) that create the possibility of monopoly rents; on the other hand, it can result in a redistribution of corruption, as new interest groups become more powerful by the new developments. The empirical evidence so far seems to suggest that more open economies improve incentives (see e.g. Ades and Di Tella (1999), Persson and Tabellini (2003, chapter 3) and Treisman (2000)). Finally, income inequality 
factors include government policies. ${ }^{10}$ Concerning government policies, the focus has been on two things. First, the beneficial effects of targeted policies, like education and redistribution. ${ }^{11}$ Second, the adverse effects of regulations, since heavy regulation and government intervention can push agents to rent seeking, tax evasion, shadow economic activities, etc. ${ }^{12}$ But there is relatively little evidence on the role of the fiscal size of the government sector, anyhow this size is measured. ${ }^{13}$ This is surprising because it is widely believed that economic performance - and the quality of incentives is an important indicator of economic performance - correlates systematically with the fiscal size of the government sector.

But it is better to take things in turn. In principle, the effect of the fiscal size of government on the quality of private incentives is ambiguous. On the one hand, government intervention can improve incentives. For instance, governments can enforce the law by financing activities like police, courts and prisons; they can educate people the benefits of trust, ethics, social cohesion and cooperation; they can redistribute income and thus create opportunities and reduce social conflict; they can build schools and pay the salaries of teachers. On the other hand, there is the counterargument that government intervention, not only requires higher taxes, but also pushes self-interested individuals further away from socially productive to unproductive activities. For instance, large public sectors can lead to tax evasion; they can foster corruption; they generate both rents and rent-seeking behavior; they cause

also results in social conflicts and anti-social activities (see e.g. Rodrik (1999), Keefer and Knack (2002) and Paldam (2002), who associate measures of income inequality with corruption).

${ }^{10}$ Government policies have always been considered to be important in shaping social behavior. For instance, Tanzi (1998, p. 565) argues that "corruption is generally connected with the activities of the state and especially with the monopoly and discretionary power of the state". Olson et al. (2000, p. 343) point out that "the structure of incentives is given by a country's institutions and economic policies and thus by its government". In Mueller (2003, p. 539), "taxes and other forms of government intervention and regulation can ... affect the choice between conducting an activity in the legitimate economy and conducting it in the underground economy". Alesina (1999) argues similarly when he compares big public sectors in developed economies to small public sectors in developing economies.

${ }^{11}$ For instance, Van Rijckeghem and Weder (2001) provide evidence that civil-service wages relative to manufacturing wages reduce corruption (however see also Treisman (2000) and La Porta et al. (1999) on this). Ades and Di Tella (1999) and Persson and Tabellini (2003, chapter 3), among many others, use measures of school enrolment as potential determinants of less corruption.

12 Johnson et al. (1998) relate the size of underground economy to indexes of the burden of regulation, taxation and corruption in a sample of 49 economies. Schneider and Enste (2000) review the literature that provides evidence that higher tax and social security contributions, as well as heavier regulation, cause shadow economic activities. Graeff and Mehlkop (2003) and Paldam (2002) use the "Economic Freedom of the World" index, developed by the Frasier Institute, while Treisman (2000) uses an index of state interference as constructed by the Institute for Management Development at Lausanne, to investigate the impact of economic freedom (or its mirror image, government regulations) on corruption.

${ }^{13}$ Exceptions include e.g. Goel and Nelson (1998) who find that corruption at the state level in the US increases with the fiscal size of state governments, and La Porta et al. (1999) who present cross-country correlations between various measures of the fiscal size of government and various proxies of rent seeking, and find (unexpectedly) an inverse relation. 
moral hazard behavior. Therefore, as always with government intervention, there should be a tradeoff in the size of government, which implies that private incentives (and economic performance in general) follow an inverted-U pattern with the size. When the size is too small, a bigger size should improve incentives. Beyond a critical size, the distorting effects dominate and a bigger size should be bad for incentives. ${ }^{14}$

When we go to the "real world", a popular belief among economists is that in most countries (especially the developed ones) the costs outweigh the benefits so that, other things equal, countries with big governments perform worse than countries with small governments. For instance, Tanzi and Schuknecht (1997, 2000) provide correlations that, in industrial countries, countries with small governments perform better than countries with big governments in terms of several socioeconomic indicators. As said above, this belief is particularly popular when the performance indicator is private incentives (tax evasion, corruption, rent seeking, moral hazard, etc, are believed to be phenomena especially associated with big-sized governments).

We sum up. The size of government is expected to be a key determinant of anti-social redistributive activities. We now look at the data.

\section{Preliminary econometric evidence}

To examine empirically the above conjectures, we use a pooled cross section of data for 64 counties (both developed and developing). We take 5-year averages for all variables over four time-periods, 1980-1985, 1985-1990, 1990-1995 and 1995-2000. Thus, ideally, we have four observations for each country. But there are missing observations for some countries in certain time periods, so that we end up with a total of 162 observations. $^{15}$

As a measure of anti-social redistributive activities, we will use the $I C R G$ index described in Section 2 above, with higher scores denoting better social behavior. The ICRG index will be regressed on a selective small number of commonly-used explanatory variables (e.g. ethnic divisions, democracy and openness), plus the key variable in our study which is the government size. As a measure of government size, we will use the variable government share in GDP,

\footnotetext{
${ }^{14}$ Tradeoffs between macro outcomes and the size of public sector are well studied (see e.g. Barro's (1990) well-known growth model and the review of the empirical literature in Mueller (2003, chapter 23)). But tradeoffs between private incentives and government size are less studied.

${ }^{15}$ For what we do in this section, we can collect data from 108 countries. However, the main constraint to the data is the construction of a measure of government efficiency described in Section 5 below. We therefore prefer to use the same sample (64 countries) throughout the paper. We report that the results reported in this section do not change if we use the bigger sample of 108 countries.
} 
which is obtained from the Penn World Tables, version 6.1 (Heston et al., 2002). ${ }^{16}$ As a measure of ethnic divisions, we will use the variable ethnic tensions provided by the IRIS dataset. ${ }^{17}$ Democracy will be measured by the Gastil Index developed by the Freedom House. To measure openness, we will use the variable openness from the Penn World Tables defined as imports plus exports over GDP in constant prices. All these variables will be averaged over the four 5-year periods. Since historical or geographical effects can still be important even after controlling for the above factors, we will follow usual practice by adding a set of regional dummies for the countries located in East Asia, Sub-Saharan Africa and Latin America, as well as for the Transition Economies.

Estimation of a regression for the ICRG index by fixed effects would not be informative in this sample, as there are several countries that have only one observation, which implies that they would have to be dropped. In addition, restricting the analysis to the within dimension of the data, would result in losing all crosscountry variation, and therefore our study would not be comparable to the relevant literature which has focused on cross-national differences. We therefore opt to estimate our regressions by pooled OLS after making two corrections (on the use of OLS techniques with panel data, see e.g. Wooldridge (2002, chapter 7)). First, we introduce a set of time dummies so as to control for possible time effects that appear to be common in all countries. We thus include a dummy for the 1985-1990 period (denoted as D1985), a dummy for 1990-1995 period (denoted as D1990) and a dummy for the 1995-2000 period (denoted as D1995). Second, we report standard errors that are robust to arbitrary heteroskedasticity and serial correlation.

The results of our basic regression are presented in column 1 of Table 1 . The government size (as measured by gov. share) has a significantly negative effect on the

\footnotetext{
${ }^{16}$ The fiscal size of government can be measured by government spending, tax revenue and the budget balance, all as shares of GDP (see e.g. Tanzi and Zee, 1997, and Persson and Tabellini, 2003). However, the tax revenue-to-GDP ratio is a problematic measure mainly because of tax evasion problems; this problem gets particularly acute when we examine social behavior since anti-social activities and tax evasion are correlated. The same can be said about the budget-to-GDP ratio since it includes tax revenues. We will therefore use common measures of government spending (as in the empirical growth literature). In this case, our primary measure will be the government share in GDP. This is government consumption expenditures to GDP and includes spending on goods and services like education and health (e.g. the salaries of professors and doctors and spending on non-capital goods), national defense, public administration, police and the judiciary system. These variables are close to the spirit of our paper. Nevertheless, we will also report results with more general measures of government spending, like the ratio of total government expenditures to GDP (available from World Development Indicators, WDI) that also includes public investment, transfers and interest payments on public debt. See below for further details.

${ }^{17}$ In cross-national analyses, Mauro (1995), Easterly and Levine (1997), Rodrik (1999), Treisman (2000) and Persson and Tabelini (2003, chapter 3) use an index of ethno linguistic fractionalization in
} 
ICRG index, supporting the popular belief that, on average, large governments are bad for private incentives. The rest of the variables exert their expected effects. Specifically, the results confirm the positive effect of democracy and the adverse effect of ethnic tensions. Openness is not significant (see above for explanations). Concerning the regional dummies, the transition economies, East Asian countries and especially Latin American countries are associated with worse incentives. Also, the time dummies make a strong case that the 1990s have been a much better decade than the 1980s. It should be pointed out that this set of explanatory variables is explaining about $76 \%$ of the variation of the ICRG index. ${ }^{18}$

Summing up this section, there is evidence that private incentives are negatively affected by the size of government. A key message of our paper is that this result, although popular, is missing an important point. Whether the effect of government size on incentives is positive or negative (or equivalently whether the government size is too small or too large) should depend explicitly on the nexus between size and efficiency of the public sector (see also e.g. Levine and Renelt (1992)). To put it differently, since government activity can have both positive and negative effects on incentives, both possibilities should be detected by the data so that countries are located all along a Laffer-type curve. Therefore, in what follows we try to go a bit deeper by taking account of government efficiency. But to do so, we first need a measure of government efficiency.

\section{A measure of government efficiency}

To measure government efficiency, we use the methodology developed by Afonso et al. (2003). We will construct sub-indices of relative Public Sector Efficiency (PSE) in certain policy areas in each country and each time period, and then take the average of

the early sixties as a proxy for ethnic tensions. Here, we prefer the IRIS index (also used by e.g. Keefer and Knack, 2002) because it is available for more countries and more time periods.

${ }^{18}$ Two remarks: First, we have alternatively used total government expenditures-to-GDP as a measure of government size but it is not significant. We believe this is because this measure includes transfers and interest payments, where the former has several effects on incentives that work in different directions, and the latter is predetermined and thus too inflexible to affect social behavior. We thus believe that the government share in GDP is more appropriate for what we do here. Second, the results are affected if we include per capita GDP as an explanatory variable. In particular, most of the other regressors lose about half of their estimated effect on the ICRG index and their estimated standard errors get higher, while the coefficient of gov. share gets insignificant (for similar results, see La Porta et al. (1999) although in a study without government size; Persson and Tabellini (2003, chapter 3), when they control for per capita income, also do not find significant effects of democracy, ethnic tensions or regional dummies on rent seeking). This is because the level of per capita income is a strong indicator of economic development; it is therefore highly correlated with (and thus absorbing the 
these sub-indices to obtain an index of aggregate government efficiency in each country and each time period.

Afonso et al. have constructed such PSEs in seven policy areas for OECD countries over the eighties and nineties. Here, we will focus on four policy areas (education, administration, infrastructure and stabilization) for 64 countries, both industrialized and developing, and four 5-year time-periods, over 1980-2000 (obviously, due to data availability, there is a trade-off between the number of countries and the number of policy areas). Note that we keep only those observations for which indexes of government efficiency in all four areas are available.

The basic insight in the methodology of Afonso et al. is to compare the performance of government in certain areas of economic activity (where these areas are directly influenced by government intervention) to the associated expenditures that the government allocates in order to achieve this particular performance. Thus, to construct a PSE index, we need a measure of Public Sector Performance (PSP) and a measure of the associated Public Sector Expenditure (PEX) for each country in each policy area in each time period. Then, the PSE will be the ratio of PSP to PEX. ${ }^{19}$

In the policy area of education, the PSP can be measured by the variable Secondary School Enrollment, while the associated PEX is the average of the variable Public Spending in Education as a percentage of GDP (both variables are available from the World Development Indicators, WDI), where we use the end of period values (or the closest to the end available) of Secondary School Enrollment. ${ }^{20}$ The resulting PSE is then a measure of government efficiency in the policy area of education.

In the policy area of administration, the PSP is measured by the end of period values of the variables Corruption in Government and Bureaucratic Quality (both obtained from the IRIS-3 dataset) ${ }^{21}$ with higher scores denoting better outcomes,

\footnotetext{
effect of) policies (e.g. the share of government in GDP, or the degree of openness) and other institutional factors (e.g. the measures of democracy, ethnic tensions, or regional dummies).

19 Afonso et al. have focused on OECD countries, where the available data cover both government performance and the associated public expenditure. Although we have tried to follow Afonso et al. in the choice of policy areas and variables used, the construction of such a rich PSE for a broader group of countries runs into data limitations, especially when looking for decomposed public expenditure data. Thus, some deviations from the variables used by Afonso et al. are inevitable. Nevertheless, the variables used here are the same in spirit.

${ }^{20}$ Afonso et al. (2003) use the same PEX, but they also include a measure of the quality of education when they construct the PSP. See below for further details.

${ }^{21}$ Afonso et al. (2003) have used very similar variables (measures of corruption, red tape, quality of judiciary and shadow economy). We prefer the IRIS-3 indices simply because they are available for the counties and time period we work with.
} 
while the PSE is obtained as in Afonso et al. (2003) by dividing this variable by the average public spending on goods and services (available from WDI).

In the policy area of infrastructure, the PSP is measured by the average of the variable Diesel Locomotives in Use as a percentage of total locomotives, and the average of the inverse of Electric Power Transmission and Distribution Losses (both variables are available from WDI). These measures are also used in Tanzi and Davoodi (1998) as indicators of the quality of infrastructure. A problem here is that the relevant PEX for infrastructure quality, which has been used by Afonso et al. for the OECD countries, is not available for the larger group of countries we work with. We therefore choose to use Total Government Expenditure (as a percentage of GDP) for PEX (this is also available from WDI), again averaged over the 5-year period.

Finally, in the policy area of stabilization, the PSP is measured by the average of the inverse of the variables Inflation Rate and Unemployment Rate (obtained from WDI), while the relevant PSE is calculated by dividing this PSP by Total Government Expenditure (as a percentage of GDP), averaged over the 5-year period. Afonso et al. also use total government spending as a measure of the expenditures of the public sector that are associated with stabilization and economic performance indicators, such as inflation and unemployment.

To make the above PSP and PEX measures (expressed in different units of measurement) comparable across countries, we follow Afonso et al. by expressing each country's PSP and PEX relative to the average PSP and PEX of all countries in each period, and this is done for all periods and for all four indexes. In other words, each country's PSP and PEX are expressed as percentages of the respective average (normalized to be 100), and in turn the PSE is obtained as the ratio of these relative PSP and PEX. ${ }^{22}$ Therefore, the resulting PSE is an index that measures the efficiency of a country relative to other countries in each period in a particular policy area. The larger the value, the more efficient the country is. This is the notion of relative efficiency in Afonso et al.

Table 2 reports the relative PSEs in the four policy areas over the most recent time-period, 1995-2000, for the 52 countries for which data are available for this time

\footnotetext{
${ }^{22}$ Since the averages of PSP and PEX are both normalized to be 100, the resulting PSE has an average around 100 (specifically, the PSEs in education and stabilization have an average of about 110, whereas the PSEs in infrastructure and administration have an average of about 125). For instance, a number of 73 for the PSE in education in Algeria over 1985-1990 means that Algeria scores 73, when all the countries in this time period score on average 110 in the policy area of education.
} 
period. ${ }^{23}$ In turn, the first column in Table 3 reports the aggregate (relative) efficiency of government in each country over 1995-2000, obtained as the simple average of the four (relative) sub-indices in Table 2. The numbers in parentheses in the same column indicate the ranking of countries according to government efficiency. With two striking exceptions (Argentina and Thailand) that score paradoxically high and are marked with a question mark, the ranking looks rather sensible at least to us (in our econometric work below, we will use both the whole sample and a sample that excludes those few countries marked with a question mark). ${ }^{24}$ As expected, OECD countries get on average better scores. However, the ranking of countries according to government efficiency does not always follow their per capita income ranking; we report that the correlation between per capita GDP and the government efficiency index of each country is, in the whole sample, $20 \%$ only.

Of course, we have to be cautious. For instance, in rich countries, like Finland or Sweden, the cost of resources used for providing public education or capital is higher than in say Uruguay or Lebanon, and this may result in an overestimation of relative efficiency in the latter group of countries. Also, government performance in a certain policy area may be overestimated when private resources are used to complement government policy; this is especially the case of education in many countries (Greece is a clear example). Actually, concerning the PSE in education, we feel that it is less related to quality performance than the PSEs in the other three policy areas. For instance, government expenditure on schools, teacher salaries or computers does not automatically mean better quality of education. ${ }^{25}$ Given these problems, we will alternatively use an index of government efficiency that excludes education, and it is thus the average of the PSEs in administration, infrastructure and stabilization only. This new index is reported in the first column of Table 4, where as before the numbers in parentheses indicate the relative ranking of countries. Again, Argentina and Thailand score paradoxically high and are marked with a question

\footnotetext{
${ }^{23}$ Results for the previous three time-periods are not reported so as to save on space. See Angelopoulos (2005) for all time-periods.

${ }^{24}$ During the other time-periods not reported here, Indonesia, Paraguay and Philippines also score paradoxically high. Thus, Argentina, Thailand, Indonesia, Paraguay and Philippines are listed as countries with a question mark.

${ }^{25}$ This is one of the reasons that Afonso et al. (2003) include test outcomes when they calculate the PSP in education. On the importance of the quality of education, see also e.g. Hanushek and Kimko (2000). Unfortunately, such data are not available for the countries and especially the time period covered in our sample.
} 
mark (in our econometric work below, we will use both the whole sample and a sample that excludes those few countries marked with a question mark). ${ }^{26}$

Summing up, the main advantage of the Afonso et al. (2003) methodology is its simplicity and logical coherence, which allow a meaningful comparison across countries. Its main weakness is that strong assumptions have to be made in order to calculate such a composite index. Of course, if one wants to focus on OECD countries only, for which more detailed data are available, it is possible to construct more sophisticated measures (for a critical assessment of different measures of public sector efficiency, see Afonso et al. (2003), Afonso (2004) and the special issue of European Economy, no. 3, 2004, on "Public finances in EMU 2004").

\section{Taking account of government efficiency and an inverted-U link}

This section addresses the main question posed in the paper: does the size effect depend on the relation between size and efficiency?

We start by simply adding government efficiency as a regressor into the simple regression of column 1 in Table $1 .^{27}$ The new results (reported in column 2 of the same table) show that the coefficient on government size remains significantly negative. Thus, by just adding government efficiency does not change anything.

We therefore move on to the main task, which is the investigation of whether there is an inverted- $U$ pattern between government size and incentives depending on the size-efficiency mix. To do so, we will work in two steps. In the first step, we will classify countries into two groups: those whose relative size is bigger than their relative efficiency (we call them inefficient governments), and those in which the opposite is true (we call them efficient governments). In the second step, we will examine whether the effect of government size on incentives differs depending on the group. Thus, the difference from the simple regressions in Table 1, is that now we classify countries according to whether they have efficient or inefficient public sectors.

The first subsection below will use the aggregate measure of government efficiency (the one reported in column 1 of Table 3), while the next subsection will

\footnotetext{
${ }^{26}$ During the other time-periods not reported here, Panama, Paraguay and Philippines also score paradoxically high. Thus, Argentina, Thailand, Panama, Paraguay and Philippines are now listed as countries with a question mark.

${ }^{27}$ In this regression, as government efficiency we use the aggregate index reported in column 1 of Table 3. The results do not change if we use instead the less general index of government efficiency that excludes the PSE in education and is reported in column 1 of Table 4.
} 
report results with the measure of government efficiency that excludes education performance (the one reported in column 1 of Table 4).

\section{Using the aggregate index of government efficiency}

Consider the first step. Relative government efficiencies are reported in column 1 of Table 3, while government sizes are reported in column 2 of the same Table (again we report results for the 1995-2000 period only). In column 3, we express each country's government size relative to the average government size in the sample. Then, whenever the number in column 3 exceeds the number in column 1, a government is called inefficient, and vice versa. Note that since each country's measures of PSP, PEX and government size are relative to their respective averages, these comparisons make sense. Take for example the first country in the list, Algeria: The government share in GDP is $25.9 \%$ (column 2 in Table 3), which implies a relative size of 161.8 (this is relative to the average which is 100). Since the relative efficiency of its public sector is only 45.5 (column 1 in Table 3), Algeria is classified as having an inefficient public sector. In turn, column 4 of Table 3 denotes countries as I (inefficient) or E (efficient) depending on whether the number in column 3 minus the number in column 1 is positive or negative. ${ }^{28}$ It is worth pointing out that by following this rule of classification about $60 \%$ of the countries are classified as being efficient in the whole sample (four 5-year time periods). For the period 1995-2000 reported here, the percentage of efficient governments is higher. Thus, there is an improvement in the nineties compared to the eighties. This is also evident from the high significance of the dummies for the nineties in our regressions.

The regression results of the second step are reported in Table 5. Column 1 shows that, in the group of inefficient governments, the government size (gov. share in GDP) significantly distorts social behavior at 5\% level. By contrast, in the group of efficient governments, the size effect is not significant. Thus, the data reveal a difference between the two groups, although ideally we would like the size effect of efficient governments to be significantly positive (but see below). Notice that, since we have included the efficiency index as a regressor, these effects are net of any direct

\footnotetext{
${ }^{28}$ Two remarks here: First, although most of the countries with efficient governments also have small governments, the two classifications do not coincide. For example, Malaysia, Canada, Chile, Argentina, Cyprus and Colombia, at certain time periods, have public sectors around, or larger than, the average and yet they are classified as having efficient governments. India, on the other hand, although scores well in terms of efficiency, it has a very big public sector so it is eventually classified as inefficient (I). We report that the correlation between government size and government efficiency is 0.28 only. Second, the OECD economies are not always classified as having efficient governments. For
} 
effects that efficiency might have on incentives. In particular, in both groups, the effect of efficiency is positive although not significant (but see below). The effects of all other variables on the $I C R G$ index make sense and remain as in Table 1.

There are several concerns regarding the above regression. First, it is possible that the administration efficiency sub-index is endogenous because the construction of the PSP in administration uses data also included in the ICRG index (see Section 5). To check that our results do not depend on this, we ignore the policy area of administration and take instead the average of the other three sub-indices (education, stabilization and infrastructure) to construct an index of government efficiency. Then, working as above and dividing governments into efficient and inefficient according to the new index, we get the results reported in column 2 of Table 5. The results are very similar to those in column 1, so that the inclusion of administration in the index of government efficiency does not seem to cause any important biases. We will therefore continue to use the general index unless said otherwise.

A second concern is the inclusion of those countries whose government efficiency scores looked paradoxical, at least to us. To make sure that the results do not depend on the inclusion of those observations, we omit these countries (defined in footnote 24 above). We then get the results reported in column 3 of Table 5. The previous results remain robust. Actually, the results become more sensible, in the sense that the efficiency indices in both groups get significantly positive.

Third, there might be a potential problem with countries for which the difference (between size and efficiency) is small. A blind application of our classification rule to these countries implies that some of them have been only marginally classified as efficient or inefficient since their measures of size and efficiency are very close to each other. A way to overcome this problem is to classify public sectors in three groups: efficient (E), inefficient (I) and non-classified $(\mathrm{N})$ (see column 5 of Table 3), where the N-group consists of counties whose efficiency is close (from above or below) to their size. ${ }^{29}$ The regression reported in column 4 of Table 5 follows this new classification. The main results again do not change (we also report that results are not sensitive to the omission of those countries mentioned in footnote 24).

example, Belgium 1980-1995, Ireland 1980-1990, Denmark 1980-1990, Portugal 1985-1995, Sweden 1985-1995 and the Netherlands 1980-1985 are classified as inefficient.

${ }^{29}$ As N-governments, we define those in which the difference between relative efficiency and relative size lies in the interval $(-15,+15)$; this amounts to about $18 \%$ of the observations in the sample. The rest of the countries exhibit differences far from this interval. 
Using the index of government efficiency that excludes performance in education

We now work as in the previous subsection but we use the measure of government efficiency that excludes the PSE in the area of education. In the first step, we again divide governments into efficient and inefficient. Whenever the number in column 2 of Table 4 exceeds the number in column 1 of the same Table, the government is called inefficient, and vice versa. The new classification of countries into efficient (E) and inefficient (I) appears in column 3 of Table 4.

The regression results of the second step are reported in Table 6. The regression in column 1 shows that in the group of inefficient governments, the government size significantly distorts social behavior at the $5 \%$ level, while in the group of efficient governments, the effect of the size is positive although not significant. All other results remain as in column 1 of Table 5 (we also report that these results do not change if we drop the administration index as we did in the previous subsection).

In the regression reported in column 2 of Table 6 , we omit those countries whose efficiency scores looked paradoxical, at least to us (defined in footnote 26 above). Now both the negative and positive effects are significant at $10 \%$ level. Thus, in the group of inefficient governments, the government size distorts social behavior, while, in the group of efficient governments, the government size improves social behavior. We therefore get a significant U-inverted pattern. Also notice that government efficiency exerts a significantly positive effect at $5 \%$ in both groups of countries. The other results are not affected. This is a good regression.

In the regression in column 3 of Table 6 , as we did in the previous subsection, we classify public sectors in three groups: efficient (E), inefficient (I) and nonclassified $(N)$, where the $N$-group consists of counties whose efficiency is close (from above or below) to their size. ${ }^{30}$ This classification appears in column 4 of Table 4 . The resulting regression in column 3 of Table 6 shows that the size effect in the I-countries is significantly negative at $10 \%$, while the size effect in the two other groups is not significant. However, results get better when we omit the same problematic countries we omitted in column 2 above. The new results, reported in column 4 of Table 6 , reveal that the size effect in the I-countries remains significantly negative at $10 \%$,

\footnotetext{
${ }^{30}$ As N-governments, we again define those in which the difference between relative efficiency and relative size lies in the interval $(-15,+15)$; this amounts to about $16 \%$ of the observations in the sample.
} 
while the size effect in the E-countries gets significantly positive at $5 \%$, and the size effect in the $\mathrm{N}$-countries is insignificant as expected. This is again a good regression.

Summing up this section, the data indicate that private incentives follow an inverted-U pattern with government size. These results are clearer when one focuses on the policy areas of administration, infrastructure and stabilization.

\section{Conclusions}

We focused on the role of government in shaping anti-social redistributive incentives. To do so, we constructed an index of government efficiency by following the methodology of Afonso et al. (2003). The main finding is that social behavior follows an inverted-U pattern with government size, where the size effect on behavior depends on the relation between size and efficiency in the public sector.

Our findings can also explain the correlations in Tanzi and Schuknecht (1997, 2000) who show that countries with small-sized governments perform better. Here we showed that when the size is small relative to efficiency, social incentives improve with the size; and, obviously, this is more possible to happen when the size is small. But we explained something beyond this. Small per se is not beautiful. What matters to incentives, and hence to the macro-economy, is the relation between size and efficiency. Just shrinking the size of government will not necessarily reduce antisocial problems like rent seeking, tax evasion and corruption.

We recognize that there are several limitations. For instance, we took the size of government, as well as its efficiency, as given. But government sizes, in particular, depend on a number of politico-economy factors varying from demographics to electoral cycles and special interests (see e.g. Persson and Tabellini (2003, chapter 3)). Also, as admitted in Section 5, it would be useful to construct more detailed indexes of public sector efficiency depending on data availability. We however believe that our work is a contribution in the right direction and leave these issues to future research.

Therefore, to reduce the possibility of getting stuck in a bad equilibrium, where agents behave anti-socially and destroy the national pie, we should improve the relation between size and efficiency in the public sector. This is not an easy task. It requires, among other things, the reallocation of government resources, and the effective and efficient use of those resources, towards identified and transparent strategic priorities. With respect to such priorities, we believe that the focus should be 
on the link between fiscal policy and long-term growth (see also the policy conclusions in the special issue of European Economy, no. 3, 2004, on "Public finances in EMU 2004"). The design of fundamentals and institutions that can provide good incentives remains a big policy challenge. 
Table 1: The effect of the size of government on anti-social activities (basic regressions)

\begin{tabular}{|c|c|c|}
\hline $\begin{array}{c}\text { Dependent variable: } \\
\text { ICRG index }\end{array}$ & $(1)$ & $(2)$ \\
\hline gov. share in GDP & $-0.175^{* * *}$ & $-0.162^{* *}$ \\
& $(0.061)$ & $(0.062)$ \\
\hline gov. efficiency & & 0.008 \\
& & $(0.009)$ \\
\hline democracy (Gastil) & $2.364 * * *$ & $2.342^{* * *}$ \\
& $(0.350)$ & $(0.349)$ \\
\hline ethnic tensions & $-1.839 * * *$ & -1.783 \\
& $(0.648)$ & $(0.641)$ \\
\hline openness & 0.009 & 0.010 \\
& $(0.013)$ & $(0.013)$ \\
\hline East Asia & $-5.922 * *$ & $-6.785 * *$ \\
& $(2.819)$ & $(2.866)$ \\
\hline Sub-Saharan Africa & 1.424 & 1.496 \\
& $(3.547)$ & $(3.512)$ \\
\hline Latin America & $-11.409 * * *$ & $-11.536 * * *$ \\
& $(1.181)$ & $(1.176)$ \\
\hline Transition Economies & $-3.611 *$ & $-3.329 *$ \\
& $(1.952)$ & $(1.994)$ \\
\hline D1985 & 0.611 & 0.588 \\
& $(1.107)$ & $(1.099)$ \\
\hline D1990 & $3.438 * * *$ & $3.374 * * *$ \\
& $(1.272)$ & $(1.267)$ \\
\hline & $4.749 * * *$ & $4.767 * * *$ \\
& $(1.490)$ & $(1.481)$ \\
\hline & $38.266 * * *$ & $37.257 * * *$ \\
$(4.026)$ \\
\hline
\end{tabular}

Notes: (i) The estimation method is OLS. (ii) There are 162 observations. (iii) Standard errors that are robust to arbitrary heteroskedasticity and serial correlation are shown in parentheses. (iv) An asterisk denotes significance at $10 \%$; two asterisks at $5 \%$; three asterisks at $1 \%$. 
Table 2: Government efficiency in four areas of policy over 1995-2000 (efficiency relative to the mean)

\begin{tabular}{|c|c|c|c|c|}
\hline Country & $\begin{array}{l}\text { Education } \\
\text { efficiency }\end{array}$ & $\begin{array}{l}\text { Administration } \\
\text { efficiency }\end{array}$ & $\begin{array}{l}\text { Stabilization } \\
\text { efficiency }\end{array}$ & $\begin{array}{l}\text { Infrastructure } \\
\text { efficiency }\end{array}$ \\
\hline Algeria & 73.000 & 39.531 & 23.709 & 45.919 \\
\hline Argentina & 136.636 & 215.013 & 413.631 & 104.336 \\
\hline Australia & 121.831 & 199.940 & 146.158 & 160.321 \\
\hline Austria & 104.243 & 128.967 & 131.048 & 95.632 \\
\hline Bulgaria & 160.557 & 65.792 & 19.432 & 50.160 \\
\hline Canada & 112.985 & 337.331 & 174.088 & 163.146 \\
\hline Chile & 141.077 & 125.352 & 107.111 & 137.734 \\
\hline Costa Rica & 61.251 & 64.098 & 94.138 & 121.553 \\
\hline Cyprus & 97.667 & 92.595 & 142.670 & 131.412 \\
\hline Czech Republic & 111.870 & 167.185 & 68.252 & 95.376 \\
\hline Denmark & 75.802 & 158.244 & 99.801 & 130.986 \\
\hline Dominican Rep. & 178.313 & 87.792 & 76.388 & 61.602 \\
\hline Egypt & 97.777 & 54.357 & 54.338 & 67.708 \\
\hline El Salvador & 108.852 & 37.429 & 137.808 & 128.684 \\
\hline Finland & 90.520 & 176.648 & 133.810 & 148.505 \\
\hline France & 107.496 & 104.653 & 96.943 & 86.932 \\
\hline Germany & 127.228 & 125.417 & 137.067 & 144.522 \\
\hline Greece & 197.128 & 117.825 & 56.349 & 114.400 \\
\hline Hungary & 122.387 & 159.674 & 31.526 & 49.759 \\
\hline Iceland & 100.322 & 79.576 & 165.161 & 123.765 \\
\hline India & 87.037 & 296.368 & 66.705 & 160.191 \\
\hline Ireland & 107.935 & 215.324 & 96.765 & 90.500 \\
\hline Israel & 74.789 & 73.810 & 39.511 & 105.754 \\
\hline Italy & 127.248 & 136.410 & 52.209 & 73.808 \\
\hline Jamaica & 90.533 & 54.721 & 27.196 & 72.062 \\
\hline Jordan & 55.116 & 49.882 & 65.722 & 95.639 \\
\hline Korea, Rep & 175.708 & 193.237 & 212.120 & 275.319 \\
\hline Lebanon & 207.091 & 77.630 & 64.750 & 46.017 \\
\hline Luxembourg & 112.022 & 121.848 & 180.954 & 23.832 \\
\hline Malaysia & 135.653 & 78.239 & 230.074 & 137.754 \\
\hline Mexico & 76.402 & 172.329 & 193.089 & 145.451 \\
\hline Namibia & 25.429 & 46.600 & 29.467 & 95.938 \\
\hline Netherlands & 127.098 & 183.132 & 87.136 & 103.704 \\
\hline New Zealand & 87.248 & 71.927 & 129.293 & 67.702 \\
\hline Nicaragua & 62.572 & 43.186 & 30.498 & 27.073 \\
\hline Norway & 84.893 & 144.364 & 125.122 & 94.871 \\
\hline Peru & 131.652 & 62.610 & 102.484 & 99.320 \\
\hline Portugal & 109.420 & 60.685 & 81.073 & 79.673 \\
\hline Romania & 128.197 & 43.906 & 48.723 & 80.452 \\
\hline South Africa & 60.474 & 124.054 & 35.687 & 118.637 \\
\hline Spain & 133.654 & 222.535 & 60.740 & 92.908 \\
\hline Sweden & 87.681 & 205.840 & 162.771 & 89.357 \\
\hline Switzerland & 100.562 & 175.177 & 308.331 & 158.982 \\
\hline Thailand & 83.685 & 94.384 & 314.540 & 155.101 \\
\hline Trinidad \& Tobago & 151.001 & 44.486 & 61.600 & 108.886 \\
\hline Tunisia & 53.611 & 53.125 & 71.616 & 83.642 \\
\hline Turkey & 154.354 & 114.961 & 54.126 & 73.552 \\
\hline UK & 127.755 & 118.877 & 78.483 & 84.424 \\
\hline Uruguay & 166.197 & 96.027 & 39.182 & 48.399 \\
\hline USA & 121.813 & 285.576 & 194.427 & 195.410 \\
\hline Venezuela & 30.174 & 138.801 & 49.410 & 97.846 \\
\hline Yemen & 44.559 & 45.298 & 12.203 & 35.142 \\
\hline
\end{tabular}


Table 3: Aggregate government efficiency (in administration, stabilization, infrastructure and education) and government size over 1995-2000

\begin{tabular}{|c|c|c|c|c|c|}
\hline Country & $\begin{array}{c}(1) \\
\text { Relative } \\
\text { government } \\
\text { efficiency }\end{array}$ & $\begin{array}{c}(2) \\
\text { Government } \\
\text { size (gov. } \\
\text { share in GDP) }\end{array}$ & $\begin{array}{c}(3) \\
\text { Relative } \\
\text { government } \\
\text { size }\end{array}$ & $\begin{array}{l}\text { (4) } \\
\text { Efficient (E) and } \\
\text { Inefficient (I) } \\
\text { governments }\end{array}$ & $\begin{array}{c}(5) \\
\text { Efficient (E), } \\
\text { Inefficient (I) and } \\
\begin{array}{c}\text { Non-classified (N) } \\
\text { governments }\end{array}\end{array}$ \\
\hline Algeria & $45.540 \quad(50)$ & 25.908 & 161.873 & I & I \\
\hline Argentina (?) & 217.404 (1) & 16.393 & 102.426 & $\mathrm{E}$ & $\mathrm{E}$ \\
\hline Australia & $157.062 \quad(7)$ & 6.896 & 43.088 & $\mathrm{E}$ & $\mathrm{E}$ \\
\hline Austria & $\begin{array}{ll}114.973 \quad(22) \\
\end{array}$ & 6.238 & 38.974 & $E$ & $E$ \\
\hline Bulgaria & $73.985 \quad(43)$ & 28.463 & 177.836 & I & I \\
\hline Canada & $196.887 \quad(4)$ & 13.791 & 86.167 & $\mathrm{E}$ & $E$ \\
\hline Chile & $127.818 \quad(14)$ & 16.566 & 103.503 & $\mathrm{E}$ & $\mathrm{E}$ \\
\hline Costa Rica & $\begin{array}{ll}85.260 & (38)\end{array}$ & 20.967 & 131.001 & I & I \\
\hline Cyprus & $116.086 \quad(21)$ & 21.470 & 134.141 & I & I \\
\hline Czech Republic & $110.671 \quad(24)$ & 11.807 & 73.771 & $\mathrm{E}$ & $\mathrm{E}$ \\
\hline Denmark & $\begin{array}{ll}116.208 \quad(20) \\
\end{array}$ & 7.211 & 45.058 & $E$ & $E$ \\
\hline Dominican Rep. & $101.024 \quad(28)$ & 23.416 & 146.299 & I & I \\
\hline Egypt & $68.545 \quad(45)$ & 9.856 & 61.582 & $\mathrm{E}$ & $\mathrm{N}$ \\
\hline El Salvador & $103.193 \quad(26)$ & 16.121 & 100.722 & $\mathrm{E}$ & $\mathrm{N}$ \\
\hline Finland & $\begin{array}{ll}137.371 \quad(11) \\
\end{array}$ & 7.271 & 45.429 & $E$ & $E$ \\
\hline France & $99.006 \quad(31)$ & 8.339 & 52.104 & $\mathrm{E}$ & $\mathrm{E}$ \\
\hline Germany & $\begin{array}{ll}133.560 \quad(13) \\
\end{array}$ & 6.421 & 40.122 & $\mathrm{E}$ & $\mathrm{E}$ \\
\hline Greece & $121.426 \quad(18)$ & 8.067 & 50.406 & $\mathrm{E}$ & $\mathrm{E}$ \\
\hline Hungary & $90.837 \quad(35)$ & 14.363 & 89.738 & $\mathrm{E}$ & $\mathrm{N}$ \\
\hline Iceland & $117.206 \quad(19)$ & 8.642 & 53.996 & $\mathrm{E}$ & $\mathrm{E}$ \\
\hline India & $152.575 \quad(8)$ & 32.056 & 200.282 & I & I \\
\hline Ireland & 127.631 (15) & 4.819 & 30.111 & $E$ & $\mathrm{E}$ \\
\hline Israel & $73.466 \quad(44)$ & 26.017 & 162.552 & I & I \\
\hline Italy & 97.419 (33) & 5.660 & 35.365 & $E$ & $E$ \\
\hline Jamaica & $61.128 \quad(48)$ & 27.019 & 168.813 & I & I \\
\hline Jordan & $66.590 \quad(46)$ & 49.992 & 312.346 & I & I \\
\hline Korea, Rep. & 214.096 (2) & 5.802 & 36.251 & $\mathrm{E}$ & $E$ \\
\hline Lebanon & $98.872 \quad(32)$ & 25.788 & 161.122 & $\mathrm{I}$ & $\mathrm{I}$ \\
\hline Luxembourg & $109.664 \quad(25)$ & 4.398 & 27.479 & $\mathrm{E}$ & $\mathrm{E}$ \\
\hline Malaysia & $145.430 \quad(10)$ & 18.777 & 117.317 & $\mathrm{E}$ & $E$ \\
\hline Mexico & $146.818 \quad(9)$ & 6.630 & 41.422 & $\mathrm{E}$ & $\mathrm{E}$ \\
\hline Namibia & $49.359 \quad(49)$ & 38.356 & 239.646 & I & I \\
\hline Netherlands & 125.268 (17) & 9.640 & 60.232 & $\mathrm{E}$ & $\mathrm{E}$ \\
\hline New Zealand & $89.043 \quad(36)$ & 8.181 & 51.117 & $\mathrm{E}$ & $\mathrm{E}$ \\
\hline Nicaragua & $40.832 \quad(51)$ & 29.834 & 186.403 & I & I \\
\hline Norway & $112.313 \quad(23)$ & 6.428 & 40.165 & $\mathrm{E}$ & $\mathrm{E}$ \\
\hline Peru & 99.017 (30) & 12.961 & 80.981 & $\mathrm{E}$ & $E$ \\
\hline Portugal & $82.713 \quad(40)$ & 12.538 & 78.335 & $\mathrm{E}$ & $\mathrm{N}$ \\
\hline Romania & $75.319 \quad(42)$ & 14.105 & 88.125 & I & $\mathrm{N}$ \\
\hline South Africa & $84.713 \quad(39)$ & 25.266 & 157.862 & I & I \\
\hline Spain & $127.459 \quad(16)$ & 6.334 & 39.574 & $\mathrm{E}$ & $\mathrm{E}$ \\
\hline Sweden & 136.412 (12) & 6.691 & 41.808 & $\mathrm{E}$ & $\mathrm{E}$ \\
\hline Switzerland & $185.763 \quad(5)$ & 10.324 & 64.507 & $\mathrm{E}$ & $\mathrm{E}$ \\
\hline Thailand (?) & 161.927 (6) & 14.118 & 88.208 & $\mathrm{E}$ & $\mathrm{E}$ \\
\hline Trinidad \& Tobago & $91.493 \quad(34)$ & 14.523 & 90.743 & $\mathrm{E}$ & $\mathrm{N}$ \\
\hline Tunisia & $65.498 \quad(47)$ & 11.599 & 72.468 & I & $\mathrm{N}$ \\
\hline Turkey & $99.248 \quad(29)$ & 14.732 & 92.044 & $E$ & $\mathrm{~N}$ \\
\hline UK & $\begin{array}{ll}102.385 \quad(27) \\
\end{array}$ & 7.134 & 44.575 & $E$ & $\mathrm{E}$ \\
\hline Uruguay & $87.451 \quad(37)$ & 18.754 & 117.177 & I & I \\
\hline USA & $199.306 \quad(3)$ & 11.231 & 70.173 & $E$ & $E$ \\
\hline Venezuela & $79.058 \quad(41)$ & 14.504 & 90.623 & I & $\mathrm{N}$ \\
\hline Yemen & $34.301 \quad(52)$ & 59.847 & 373.915 & I & I \\
\hline
\end{tabular}


Table 4: Aggregate government efficiency (in administration, stabilization and infrastructure) and government size over 1995-2000

\begin{tabular}{|c|c|c|c|c|}
\hline Country & $\begin{array}{c}\text { (1) } \\
\text { Relative } \\
\text { government } \\
\text { efficiency } \\
\end{array}$ & $\begin{array}{c}\text { (2) } \\
\text { Relative government } \\
\text { size } \\
\text { (as in Table 3) } \\
\end{array}$ & $\begin{array}{l}\text { (3) } \\
\text { Efficient (E) and } \\
\text { Inefficient (I) } \\
\text { governments } \\
\end{array}$ & $\begin{array}{c}\text { (4) } \\
\text { Efficient (E), Inefficient (I) } \\
\text { and Non-classified (N) } \\
\text { governments }\end{array}$ \\
\hline Algeria & $36.386 \quad(50)$ & 161.873 & $\mathrm{I}$ & I \\
\hline Argentina (?) & $244.32 \quad(1)$ & 102.426 & $\mathrm{E}$ & $\mathrm{E}$ \\
\hline Australia & $168.806 \quad(9)$ & 43.088 & $\mathrm{E}$ & $\mathrm{E}$ \\
\hline Austria & $118.549 \quad(22)$ & 38.974 & $\mathrm{E}$ & $\mathrm{E}$ \\
\hline Bulgaria & $45.128 \quad(49)$ & 177.836 & $\mathrm{I}$ & $\mathrm{I}$ \\
\hline Canada & $224.855 \quad(4)$ & 86.167 & $\mathrm{E}$ & E \\
\hline Chile & $123.399 \quad(18)$ & 103.503 & $\mathrm{E}$ & $\mathrm{E}$ \\
\hline Costa Rica & $93.263 \quad(30)$ & 131.001 & $\mathrm{I}$ & $\mathrm{I}$ \\
\hline Cyprus & $122.226 \quad(20)$ & 134.141 & $\mathrm{I}$ & $\mathrm{N}$ \\
\hline Czech Republic & $110.271 \quad(23)$ & 73.771 & $\mathrm{E}$ & $\mathrm{E}$ \\
\hline Denmark & $129.677 \quad(15)$ & 45.058 & $\mathrm{E}$ & $E$ \\
\hline Dominican Rep. & $75.261 \quad(37)$ & 146.299 & $\mathrm{I}$ & $\mathrm{I}$ \\
\hline Egypt & $58.801 \quad(45)$ & 61.582 & $\mathrm{I}$ & $\mathrm{N}$ \\
\hline El Salvador & $101.307 \quad(25)$ & 100.722 & $\mathrm{E}$ & $\mathrm{N}$ \\
\hline Finland & $152.988 \quad(10)$ & 45.429 & $\mathrm{E}$ & $\mathrm{E}$ \\
\hline France & $96.176 \quad(27)$ & 52.104 & $E$ & $\mathrm{E}$ \\
\hline Germany & $135.670 \quad(13)$ & 40.122 & $E$ & $E$ \\
\hline Greece & $96.191 \quad(26)$ & 50.406 & $E$ & $\mathrm{E}$ \\
\hline Hungary & $80.320 \quad(36)$ & 89.738 & I & $\mathrm{N}$ \\
\hline Iceland & $122.834 \quad(19)$ & 53.996 & $\mathrm{E}$ & $\mathrm{E}$ \\
\hline India & $174.421 \quad(7)$ & 200.282 & $\mathrm{I}$ & $\mathrm{I}$ \\
\hline Ireland & $134.196 \quad(14)$ & 30.111 & $\mathrm{E}$ & $\mathrm{E}$ \\
\hline Israel & $73.025 \quad(39)$ & 162.552 & $\mathrm{I}$ & $\mathrm{I}$ \\
\hline Italy & $87.476 \quad(34)$ & 35.365 & $\mathrm{E}$ & $E$ \\
\hline Jamaica & $51.326 \quad(48)$ & 168.813 & $\mathrm{I}$ & $\mathrm{I}$ \\
\hline \begin{tabular}{|l|} 
Jordan \\
\end{tabular} & $70.414 \quad(41)$ & 312.346 & $\mathrm{I}$ & $\mathrm{I}$ \\
\hline Korea, Rep & $226.892 \quad(2)$ & 36.251 & $\mathrm{E}$ & $E$ \\
\hline Lebanon & $62.799 \quad(43)$ & 161.122 & $\mathrm{I}$ & $\mathrm{I}$ \\
\hline Luxembourg & $108.878 \quad(24)$ & 27.479 & $\mathrm{E}$ & $\mathrm{E}$ \\
\hline Malaysia & $148.689 \quad(12)$ & 117.317 & $\mathrm{E}$ & $\mathrm{E}$ \\
\hline Mexico & $170.290 \quad(8)$ & 41.422 & $\mathrm{E}$ & $E$ \\
\hline Namibia & $57.335 \quad(47)$ & 239.646 & $\mathrm{I}$ & $\mathrm{I}$ \\
\hline Netherlands & $124.658 \quad(17)$ & 60.232 & $E$ & $E$ \\
\hline New Zealand & $89.641 \quad(32)$ & 51.117 & $\mathrm{E}$ & $\mathrm{E}$ \\
\hline Nicaragua & $33.586 \quad(51)$ & 186.403 & $\mathrm{I}$ & $\mathrm{I}$ \\
\hline \begin{tabular}{|l|} 
Norway \\
\end{tabular} & $121.452 \quad(21)$ & 40.165 & $\mathrm{E}$ & $\mathrm{E}$ \\
\hline Peru & $88.138 \quad(33)$ & 80.981 & $\mathrm{E}$ & $\mathrm{N}$ \\
\hline Portugal & $73.810 \quad(38)$ & 78.335 & I & $\mathrm{N}$ \\
\hline Romania & $57.694 \quad(46)$ & 88.125 & $\mathrm{I}$ & $\mathrm{I}$ \\
\hline South Africa & $92.793 \quad(31)$ & 157.862 & I & I \\
\hline Spain & $125.394 \quad(16)$ & 39.574 & $\mathrm{E}$ & $\mathrm{E}$ \\
\hline Sweden & $152.656 \quad(11)$ & 41.808 & $E$ & $E$ \\
\hline Switzerland & $214.163(5)$ & 64.507 & $\mathrm{E}$ & $\mathrm{E}$ \\
\hline Thailand (?) & $188.008 \quad(6)$ & 88.208 & $\mathrm{E}$ & $\mathrm{E}$ \\
\hline Trinidad \& Tobago & $71.657 \quad(40)$ & 90.743 & I & I \\
\hline Tunisia & $69.461 \quad(42)$ & 72.468 & I & $\mathrm{N}$ \\
\hline Turkey & $80.880 \quad(35)$ & 92.044 & $\mathrm{I}$ & $\mathrm{N}$ \\
\hline UK & $93.928 \quad(29)$ & 44.575 & E & $\mathrm{E}$ \\
\hline Uruguay & $61.203 \quad(44)$ & 117.177 & $\mathrm{I}$ & $\mathrm{I}$ \\
\hline USA & 225.137 (3) & 70.173 & $\mathrm{E}$ & $\mathrm{E}$ \\
\hline Venezuela & $95.353 \quad(28)$ & 90.623 & $\mathrm{E}$ & $\mathrm{N}$ \\
\hline Yemen & $30.881 \quad(52)$ & 373.915 & $\mathrm{I}$ & $\mathrm{I}$ \\
\hline
\end{tabular}


Table 5: The effects of the size and efficiency of government on anti-social activities (efficiency as in Table 3)

\begin{tabular}{|c|c|c|c|c|c|}
\hline $\begin{array}{l}\text { Dependent variable: } \\
\text { ICRG index }\end{array}$ & (1) & (2) & (3) & $\begin{array}{l}\text { Dep. variable: } \\
\text { ICRG index }\end{array}$ & (4) \\
\hline $\begin{array}{l}\text { gov. share in GDP } \\
\text { (inefficient govs) }\end{array}$ & $\begin{array}{c}-0.191 * * \\
(0.076)\end{array}$ & $\begin{array}{l}-0.190 * * \\
(0.074)\end{array}$ & $\begin{array}{c}-0.175^{* *} \\
(0.076)\end{array}$ & $\begin{array}{l}\text { gov. share in GDP } \\
\text { (inefficient govs, I) }\end{array}$ & $\begin{array}{c}-0.221^{* *} \\
(0.084)\end{array}$ \\
\hline $\begin{array}{l}\text { gov. share in GDP } \\
\text { (efficient govs) }\end{array}$ & $\begin{array}{l}-0.142 \\
(0.163)\end{array}$ & $\begin{array}{l}-0.257 \\
(0.187)\end{array}$ & $\begin{array}{l}-0.145 \\
(0.174)\end{array}$ & $\begin{array}{c}\text { gov. share in GDP } \\
\text { (non-classified govs, N) }\end{array}$ & $\begin{array}{c}0.674 \\
(0.495)\end{array}$ \\
\hline $\begin{array}{l}\text { gov. efficiency } \\
\text { (inefficient govs) }\end{array}$ & $\begin{array}{c}0.028 \\
(0.023)\end{array}$ & $\begin{array}{c}0.003 \\
(0.023)\end{array}$ & $\begin{array}{l}0.049 * \\
(0.025)\end{array}$ & $\begin{array}{l}\text { gov. share in GDP } \\
\text { (efficient govs, E) }\end{array}$ & $\begin{array}{l}-0.014 \\
(0.168)\end{array}$ \\
\hline \multirow[t]{3}{*}{$\begin{array}{l}\text { gov. efficiency } \\
\text { (efficient govs) }\end{array}$} & $\begin{array}{c}0.009 \\
(0.010)\end{array}$ & $\begin{array}{c}0.001 \\
(0.004)\end{array}$ & $\begin{array}{c}0.032 * * * \\
(0.011)\end{array}$ & $\begin{array}{c}\text { gov. efficiency } \\
\text { (inefficient govs, I) }\end{array}$ & $\begin{array}{c}0.041 \\
(0.024)\end{array}$ \\
\hline & & & & $\begin{array}{l}\text { gov. efficiency (non- } \\
\text { classified govs, } N)\end{array}$ & $\begin{array}{l}-0.143 * \\
(0.083)\end{array}$ \\
\hline & & & & $\begin{array}{c}\text { gov. efficiency (efficient } \\
\text { govs, E) }\end{array}$ & $\begin{array}{c}0.005 \\
(0.010)\end{array}$ \\
\hline democracy (Gastil) & $\begin{array}{l}2.284 * * * \\
(0.359)\end{array}$ & $\begin{array}{c}2.351 * * * \\
(0.362)\end{array}$ & $\begin{array}{c}-2.116^{* * *} \\
(0.354)\end{array}$ & democracy (Gastil) & $\begin{array}{c}2.129 * * * \\
(0.352)\end{array}$ \\
\hline ethnic tensions & $\begin{array}{c}-1.903 * * * \\
(0.658)\end{array}$ & $\begin{array}{c}-1.790 * * * \\
(0.657)\end{array}$ & $\begin{array}{c}-1.509 * * \\
(0.671)\end{array}$ & ethnic tensions & $\begin{array}{c}-1.808 * * * \\
(0.600)\end{array}$ \\
\hline openness & $\begin{array}{c}0.010 \\
(0.014) \\
\end{array}$ & $\begin{array}{c}0.009 \\
(0.014) \\
\end{array}$ & $\begin{array}{c}0.017 \\
(0.013) \\
\end{array}$ & openness & $\begin{array}{c}0.013 \\
(0.013) \\
\end{array}$ \\
\hline East Asia & $\begin{array}{l}-6.770 * * \\
(2.909)\end{array}$ & $\begin{array}{l}-5.846^{* *} \\
(2.819)\end{array}$ & $\begin{array}{c}-7.278 * * * \\
(1.874)\end{array}$ & East Asia & $\begin{array}{c}-7.160 * * \\
(2.775)\end{array}$ \\
\hline Sub-Saharan Africa & $\begin{array}{c}1.666 \\
(3.236)\end{array}$ & $\begin{array}{c}1.106 \\
(3.397)\end{array}$ & $\begin{array}{c}1.591 \\
(2.981)\end{array}$ & Sub-Saharan Africa & $\begin{array}{c}1.512 \\
(2.963)\end{array}$ \\
\hline Latin America & $\begin{array}{c}-11.844 * * * \\
(1.166)\end{array}$ & $\begin{array}{c}-11.673 * * * \\
(1.234)\end{array}$ & $\begin{array}{c}-11.135^{* * *} \\
(1.198)\end{array}$ & Latin America & $\begin{array}{c}-11.765^{* * * *} \\
(1.113)\end{array}$ \\
\hline $\begin{array}{l}\text { Transition } \\
\text { Economies }\end{array}$ & $\begin{array}{l}-3.472^{*} \\
(1.984)\end{array}$ & $\begin{array}{l}-3.777^{*} \\
(1.898)\end{array}$ & $\begin{array}{l}-2.744 \\
(2.005)\end{array}$ & Transition Economies & $\begin{array}{l}-2.983 \\
(2.219)\end{array}$ \\
\hline$D 1985$ & $\begin{array}{c}0.534 \\
(1.087)\end{array}$ & $\begin{array}{c}0.660 \\
(1.164)\end{array}$ & $\begin{array}{c}0.804 \\
(1.131)\end{array}$ & D1985 & $\begin{array}{c}0.342 \\
(1.251)\end{array}$ \\
\hline$D 1990$ & $\begin{array}{c}3.335 * * * \\
(1.209)\end{array}$ & $\begin{array}{c}3.324 * * * \\
(1.255)\end{array}$ & $\begin{array}{c}3.171 * * * \\
(1.210)\end{array}$ & $D 1990$ & $\begin{array}{c}3.368 * * * \\
(1.302)\end{array}$ \\
\hline$D 1995$ & $\begin{array}{c}4.823 * * * \\
(1.427)\end{array}$ & $\begin{array}{c}4.703 * * * \\
(1.482)\end{array}$ & $\begin{array}{c}\text { 4. } 378^{* * * *} \\
(1.426)\end{array}$ & $D 1995$ & $\begin{array}{c}4.744 * * * \\
(1.460)\end{array}$ \\
\hline Constant & $\begin{array}{c}36.085 * * * \\
(3.993)\end{array}$ & $\begin{array}{c}38.992 * * * \\
(3.937)\end{array}$ & $\begin{array}{c}34.735 * * * \\
(3.907)\end{array}$ & constant & $\begin{array}{c}35.956 * * * \\
(3.651)\end{array}$ \\
\hline $\mathrm{R}^{2}$ & $76.69 \%$ & $76.26 \%$ & $76.62 \%$ & $\mathrm{R}^{2}$ & $78.04 \%$ \\
\hline Observations & 162 & 162 & 153 & Observations & 162 \\
\hline
\end{tabular}

Notes: (i) See the notes in Table 1. (ii) In columns (1)-(3), efficient (inefficient) governments are those whose relative size is smaller (larger) than relative efficiency. In column (4), efficient, inefficient and non-classified governments are as defined in the text. 
Table 6: The effects of the size and efficiency of government on anti-social activities (efficiency as in Table 4)

\begin{tabular}{|c|c|c|c|c|c|}
\hline $\begin{array}{l}\text { Dependent variable: } \\
\text { ICRG index }\end{array}$ & (1) & (2) & $\begin{array}{l}\text { Dep. variable: } \\
\text { ICRG index }\end{array}$ & (3) & (4) \\
\hline $\begin{array}{l}\text { gov. share in GDP } \\
\text { (inefficient govs) }\end{array}$ & $\begin{array}{c}-0.144 * * \\
(0.071)\end{array}$ & $\begin{array}{l}-0.138^{*} \\
(0.073)\end{array}$ & $\begin{array}{l}\text { gov. share in GDP } \\
\text { (inefficient govs, I) }\end{array}$ & $\begin{array}{l}-0.148 * \\
(0.077)\end{array}$ & $\begin{array}{l}-0.147^{*} \\
(0.080)\end{array}$ \\
\hline $\begin{array}{l}\text { gov. share in GDP } \\
\text { (efficient govs) }\end{array}$ & $\begin{array}{c}0.137 \\
(0.124)\end{array}$ & $\begin{array}{l}0.179 * \\
(0.106)\end{array}$ & $\begin{array}{c}\text { gov. share in GDP } \\
\text { (non-classified } \\
\text { govs, } N \text { ) } \\
\end{array}$ & $\begin{array}{l}-0.925 \\
(0.954)\end{array}$ & $\begin{array}{l}-0.836 \\
(0.990)\end{array}$ \\
\hline $\begin{array}{l}\text { gov. efficiency } \\
\text { (inefficient govs) }\end{array}$ & $\begin{array}{c}0.023 \\
(0.020) \\
\end{array}$ & $\begin{array}{l}0.050 * * \\
(0.023) \\
\end{array}$ & $\begin{array}{l}\text { gov. share in GDP } \\
\text { (efficient govs, E) }\end{array}$ & $\begin{array}{c}0.154 \\
(0.145)\end{array}$ & $\begin{array}{l}0.249 * * \\
(0.120)\end{array}$ \\
\hline \multirow[t]{3}{*}{$\begin{array}{l}\text { gov. efficiency } \\
\text { (efficient govs) }\end{array}$} & $\begin{array}{c}0.004 \\
(0.008) \\
\end{array}$ & $\begin{array}{c}0.027 * * \\
(0.009) \\
\end{array}$ & $\begin{array}{c}\text { gov. efficiency } \\
\text { (inefficient govs, I) }\end{array}$ & $\begin{array}{c}0.027 \\
(0.023) \\
\end{array}$ & $\begin{array}{c}0.057 * * \\
(0.024) \\
\end{array}$ \\
\hline & & & $\begin{array}{c}\text { gov. efficiency } \\
\text { (non-classified } \\
\text { govs, N) }\end{array}$ & $\begin{array}{c}0.159 \\
(0.157)\end{array}$ & $\begin{array}{c}0.168 \\
(0.161)\end{array}$ \\
\hline & & & $\begin{array}{c}\text { gov. efficiency } \\
\text { (efficient govs, E) }\end{array}$ & $\begin{array}{c}0.004 \\
(0.008) \\
\end{array}$ & $\begin{array}{l}0.025^{* *} \\
(0.008) \\
\end{array}$ \\
\hline democracy (Gastil) & $\begin{array}{c}2.331 * * * \\
(0.338)\end{array}$ & $\begin{array}{c}1.900 * * * \\
(0.356)\end{array}$ & democracy (Gastil) & $\begin{array}{l}2.310 * * * \\
(0.349)\end{array}$ & $\begin{array}{c}1.831 * * * \\
(0.360)\end{array}$ \\
\hline ethnic tensions & $\begin{array}{c}-1.807 * * * \\
(0.638)\end{array}$ & $\begin{array}{c}-1.539 * * \\
(0.592) \\
\end{array}$ & ethnic tensions & $\begin{array}{c}-1.789 * * * \\
(0.655)\end{array}$ & $\begin{array}{c}-1.490 * * * \\
(0.569)\end{array}$ \\
\hline openness & $\begin{array}{c}0.008 \\
(0.012)\end{array}$ & $\begin{array}{c}0.018 \\
(0.011)\end{array}$ & openness & $\begin{array}{c}0.007 \\
(0.012)\end{array}$ & $\begin{array}{l}0.017 \\
(.011)\end{array}$ \\
\hline East Asia & $\begin{array}{l}-6.803 * * \\
(2.855)\end{array}$ & $\begin{array}{c}-7.789 * * * \\
(1.428)\end{array}$ & East Asia & $\begin{array}{l}-6.758 * * \\
(2.932)\end{array}$ & $\begin{array}{c}-7.537 * * * \\
(1.405)\end{array}$ \\
\hline $\begin{array}{c}\text { Sub-Saharan } \\
\text { Africa }\end{array}$ & $\begin{array}{c}1.894 \\
(3.447) \\
\end{array}$ & $\begin{array}{c}1.767 \\
(3.100) \\
\end{array}$ & $\begin{array}{c}\text { Sub-Saharan } \\
\text { Africa }\end{array}$ & $\begin{array}{c}1.815 \\
(3.411) \\
\end{array}$ & $\begin{array}{c}1.598 \\
(2.958) \\
\end{array}$ \\
\hline Latin America & $\begin{array}{c}-11.542 * * * \\
(1.148) \\
\end{array}$ & $\begin{array}{c}-10.402 * * * \\
(1.197)\end{array}$ & Latin America & $\begin{array}{c}-11.510 * * * \\
(1.203)\end{array}$ & $\begin{array}{c}-10.350 * * * \\
(1.230)\end{array}$ \\
\hline $\begin{array}{l}\text { Transition } \\
\text { Economies }\end{array}$ & $\begin{array}{l}-2.779 \\
(2.280) \\
\end{array}$ & $\begin{array}{l}-1.947 \\
(2.253) \\
\end{array}$ & $\begin{array}{l}\text { Transition } \\
\text { Economies }\end{array}$ & $\begin{array}{l}-2.726 \\
(2.329) \\
\end{array}$ & $\begin{array}{l}-1.843 \\
(2.364) \\
\end{array}$ \\
\hline D1985 & $\begin{array}{c}0.491 \\
(1.072)\end{array}$ & $\begin{array}{c}0.632 \\
(1.177)\end{array}$ & D1985 & $\begin{array}{c}0.504 \\
(1.171)\end{array}$ & $\begin{array}{c}0.501 \\
(1.268)\end{array}$ \\
\hline$D 1990$ & $\begin{array}{c}3.581 * * * \\
(1.258)\end{array}$ & $\begin{array}{c}3.314 * * * \\
(1.290)\end{array}$ & $D 1990$ & $\begin{array}{c}3.581 * * * \\
(1.295)\end{array}$ & $\begin{array}{c}3.212 * * * \\
(1.315)\end{array}$ \\
\hline$D 1995$ & $\begin{array}{c}4.962 * * * \\
(1.418)\end{array}$ & $\begin{array}{c}4.319 * * * \\
(1.451)\end{array}$ & $D 1995$ & $\begin{array}{c}5.022 * * * \\
(1.445)\end{array}$ & $\begin{array}{c}4.334 * * * \\
(1.477)\end{array}$ \\
\hline constant & $\begin{array}{l}35.081 * * * \\
(3.755)\end{array}$ & $\begin{array}{c}32.137 * * * \\
(4.012)\end{array}$ & constant & $\begin{array}{c}35.031 * * * \\
(3.776)\end{array}$ & $\begin{array}{c}32.095 * * * \\
(3.843)\end{array}$ \\
\hline $\mathrm{R}^{2}$ & $77.92 \%$ & $78.28 \%$ & $\mathrm{R}^{2}$ & $77.96 \%$ & $78.63 \%$ \\
\hline Observations & 162 & 153 & Observations & 162 & 153 \\
\hline
\end{tabular}

Notes: (i) See the notes in Table 1. (ii) In columns (1) and (2), efficient (inefficient) governments are those whose relative size is smaller (larger) than relative efficiency. In columns (3) and (4), efficient, inefficient and non-classified governments are as defined in the text. 


\section{REFERENCES}

Ades A. and R. di Tella (1999): Rents, competition and corruption, American Economic Review, 89, 982-993.

Afonso A. (2004): A note on public spending efficiency, CESifo DICE Report 1/2004, 35-39.

Afonso A., L. Schuknecht and V. Tanzi (2003): Public sector efficiency: An international comparison, ECB Working Paper, no. 242.

Alesina A. (1999): Too large and too small governments, in Economic Policy \& Equity, edited by V. Tanzi, K. Chu and S. Gupta, International Monetary Fund, Washington, D.C.

Alesina A. and A. Drazen (1991): Why are stabilizations delayed?, American Economic Review, $81,1170-88$.

Angelopoulos K. (2005): Market vs. policy failures and economic growth, Ph.D. thesis (in preparation), Department of International and European Economic Studies, Athens University of Economics \& Business, Mimeo.

Barro R. (1990): Government spending in a simple model of economic growth, Journal of Political Economy, 98, S103-S125.

Barro R. (1997): Determinants of Economic Growth: A Cross-Country Empirical Study, The MIT Press, Cambridge, Mass.

Barro R. and X. Sala-i-Martin (2004): Economic Growth, Second edition, The MIT Press, Cambridge, Mass.

Baumol W. J. (1990): Entrepreneurship: Productive, unproductive and destructive, Journal of Political Economy, 98, 893-921.

Benhabib J. and A. Rustichini (1996): Social conflict and growth, Journal of Economic Growth, 1, 125-142.

Cooper R. and A. John (1988): Coordinating coordination failures in Keynesian models, Quarterly Journal of Economics, 103, 441-463.

Drazen A. (2000): Political Economy in Macroeconomics, Princeton University Press, Princeton, New Jersey.

Easterly W. and R. Levine (1997): Africa's growth tragedy: Policies and ethnic divisions, Quarterly Journal of Economics, 112, 1203-1250.

Economides G., S. Kalyvitis and A. Philippopoulos (2004): Do foreign aid transfers distort incentives and hurt growth? Theory and evidence from 75 aid-recipient countries, CESifo Working Paper, no. 1156.

Goel R. K. and M. A. Nelson (1998): Corruption and government size: A disaggregated analysis, Public Choice, 97, 107-120. 
Ghura D. (2002): Tax revenue in Sub-Saharan Africa: Effects of economic policies and corruption, in Governance, Corruption and Economic Performance, edited by Abed G. T. and S. Gupta, International Monetary Fund, Washington, D.C.

Graeff P. and G. Mehlkop (2003): The impact of economic freedom on corruption: different patterns for rich and poor countries, European Journal of Political Economy, 19, 605-620.

Grossman H. and J. Mendoza (2003): Scarcity and appropriative competition, European Journal of Political Economy, 19, 747-758.

Gupta S., H. R. Davoodi and E. R. Tiongson (2001): Corruption and the provision of health care and education services, in The Political Economy of Corruption, edited by A. K. Jain, Rootledge, London. Also reprinted in Governance, Corruption and Economic Performance, edited by Abed G. T. and S. Gupta, International Monetary Fund, Washington, D.C.

Gupta S., L. de Mello and R. Sharan (2001): Corruption and military spending, European Journal of Political Economy, 17, 749-777. Also reprinted in Governance, Corruption and Economic Performance, edited by Abed G. T. and S. Gupta, International Monetary Fund, Washington, D.C.

Hall R. E. and C. I. Jones (1999): Why do some countries produce so much more output per worker than others?, Quarterly Journal of Economics, 114, 83-116.

Hanushek E. A. and D. D. Kimko (2000): Schooling, labor-force quality and the growth of nations, American Economic Review, 90, 1184-1208.

Heston A., R. Summers and B. Aten (2002): Penn World Table Version 6.1, Center for International Comparisons at the University of Pennsylvania (CICUP).

Johnson S., D. Kaufman and P. Zoido-Lobaton (1998): Regulatory discretion and the unofficial economy, American Economic Review, 88, 387-392.

Kaufmann D., A. Kraay., and M. Mastruzzi (2003): "Governance matters III: Governance indicators for 1996-2002”, World Bank Policy Research Working Paper No.3106, Washington, D.C.

Keefer P. and S. Knack (2002): Polarization, politics and property rights: Links between inequality and growth, Public Choice, 111, 127-154.

Knack S. and P. Keefer (1995): Institutions and economic performance: Cross-country tests using alternative institutional measures, Economics and Politics, 7, 207-227.

Knack S. and P. Keefer (1997): Does social capital have an economic payoff? A cross-country investigation, Quarterly Journal of Economics, 112, 1251-1287.

Krueger A. (1974): The political economy of the rent seeking society, American Economic Review, 64, 291-303.

La Porta R., F. Lopez-de-Silanes, A. Shleifer, and R. Vishny (1999): The quality of government, Journal of Law, Economics and Organization, 15, 222-279.

Laffont J.J. and D. Martimort (2002): The Theory of Incentives. Princeton University Press, Princeton. 
Lane P. and A. Tornell (1996): Power, growth and the voracity effect, Journal of Economic Growth, 1, 125-142.

Leite C. and J. Weidmann (2002): Does mother nature corrupt? Natural resources, corruption and economic growth, in Governance, Corruption and Economic Performance, edited by Abed G. T. and S. Gupta, International Monetary Fund, Washington, D.C.

Levine R. and D. Renelt (1992): A sensitivity analysis of cross-country growth regressions, American Economic Review, 82, 942-63.

Mauro P. (1995): Corruption and growth, Quarterly Journal of Economics, 110, 681-712.

Mauro P. (1998): Corruption and the composition of government expenditures, Journal of Public Economics, 69, 263-279. Also reprinted in Governance, Corruption and Economic Performance, edited by Abed G. T. and S. Gupta, International Monetary Fund, Washington, D.C.

Mauro P. (2002): The persistence of corruption and slow economic growth, IMF Working Paper, 02/213, International Monetary Fund, Washington.

Mohtadi H. and T. Roe (1998): Growth, lobbying and public goods, European Journal of Political Economy, 14, 453-473.

Mohtadi H. and T. Roe (2003): Democracy, rent seeking, public spending and growth, Journal of Public Economics, 87, 445-466.

Mueller D. (2003): Public Choice III. Cambridge University Press, Cambridge.

Murphy K., A. Shleifer and R. Vishny (1991): The allocation of talent: Implications for growth, Quarterly Journal of Economics, 106, 503-530.

North D. C. (1990): Institutions, Institutional Change and Economic Performance, Cambridge University Press, Cambridge.

Olson M. (1982): The Rise and Decline of Nations, New Haven, Yale University Press.

Olson M., N. Sarna and A. Swamy (2000): Governance and growth: A simple hypothesis explaining cross-country differences in productivity growth, Public Choice, 102, 341-364.

Paldam M. (2002): The cross-country pattern of corruption: Economics, culture and the seesaw dynamics, European Journal of Political Economy, 18, 215-240.

Park H. and A. Philippopoulos (2003): On the dynamics of growth and fiscal policy with redistributive transfers, Journal of Public Economics, 87, 515-538.

Park H., A. Philippopoulos and V. Vassilatos (2003): On the optimal size of public sector under rent seeking competition from state coffers, CESifo Working Paper, no. 991.

Persson T. and G. Tabellini (2000): Political Economics: Explaining Economic Policy, The MIT Press, Cambridge, Mass.

Persson T. and G. Tabellini (2003): The Economic Effects of Constitutions. The MIT Press, Cambridge, Mass. 
Persson T., G. Tabellini and F. Trebbi (2003): Electoral Rules and Corruption, Journal of the European Economic Association, 4, 958-989.

Rodrik D. (1999): Where did all the growth go? External shocks, social conflict and growth collapses, Journal of Economic Growth, 4, 385-412.

Rose-Ackerman S. (1999): Corruption and Government, Cambridge University Press, Cambridge.

Schneider F. and D. H. Enste (2000): Shadow economies: Size, causes and consequences, Journal of Economic Literature, 38, 77-114.

Tanzi V. (1998): Corruption around the world: Causes, consequences, scope and cures, IMF Staff Papers, 45, 559-594. Also reprinted in Governance, Corruption and Economic Performance, edited by Abed G. T. and S. Gupta, International Monetary Fund, Washington, D.C.

Tanzi V. and H. R. Davoodi (1998): Corruption, public investment and growth, in The Welfare State, Public Investment and Growth, edited by H. Shibata and T. Ihori, Springer-Verlag Tokyo. Also reprinted in Governance, Corruption and Economic Performance, edited by Abed G. T. and S. Gupta, International Monetary Fund, Washington, D.C.

Tanzi V. and L. Schuknecht (1997): Reconsidering the fiscal role of the government: The international perspective, American Economic Review, 87, 164-168.

Tanzi V. and L. Schuknecht (2000): Public Spending in the 20th Century: A Global Perspective, Cambridge University Press, Cambridge.

Tanzi V. and H. Zee (1997): Fiscal policy and long-run growth, IMF Staff Papers, 44, 179-209.

Tirole J. (1996): A theory of collective reputations (with applications to the persistence of corruption and to firm quality), Review of Economic Studies, 63, 1-22.

Tornell A. and P. Lane (1999): The voracity effect, American Economic Review, 89, 22-46.

Treisman D. (2000): The causes of corruption: A cross-national study, Journal of Public Economics, 76, 399-457.

Tullock G. (1967): The welfare costs of tariffs, monopolies and theft, Western Economic Journal, $5,224-232$.

Van Rijckeghem C. and B. Weder (2001): Bureaucratic corruption and the rate of temptation: Do wages in the civil service affect corruption, and by how much?, Journal of Development Economics, 65, 307-331. Also reprinted in Governance, Corruption and Economic Performance, edited by Abed G. T. and S. Gupta, International Monetary Fund, Washington, D.C.

Wooldridge J. W. (2002): Econometric Analysis of Cross Section and Panel Data, The MIT Press, Cambridge, Mass.

Zak P. and S. Knack (2001): Trust and growth, Economic Journal, 111, 295-321. 


\title{
CESifo Working Paper Series
}

\author{
(for full list see www.cesifo.de)
}

1362 Christa Hainz, Quality of Institutions, Credit Markets and Bankruptcy, December 2004

1363 Jerome L. Stein, Optimal Debt and Equilibrium Exchange Rates in a Stochastic Environment: an Overview, December 2004

1364 Frank Heinemann, Rosemarie Nagel and Peter Ockenfels, Measuring Strategic Uncertainty in Coordination Games, December 2004

1365 José Luis Moraga-González and Jean-Marie Viaene, Anti-Dumping, Intra-Industry Trade and Quality Reversals, December 2004

1366 Harry Grubert, Tax Credits, Source Rules, Trade and Electronic Commerce: Behavioral Margins and the Design of International Tax Systems, December 2004

1367 Hans-Werner Sinn, EU Enlargement, Migration and the New Constitution, December 2004

1368 Josef Falkinger, Noncooperative Support of Public Norm Enforcement in Large Societies, December 2004

1369 Panu Poutvaara, Public Education in an Integrated Europe: Studying to Migrate and Teaching to Stay?, December 2004

1370 András Simonovits, Designing Benefit Rules for Flexible Retirement with or without Redistribution, December 2004

1371 Antonis Adam, Macroeconomic Effects of Social Security Privatization in a Small Unionized Economy, December 2004

1372 Andrew Hughes Hallett, Post-Thatcher Fiscal Strategies in the U.K.: An Interpretation, December 2004

1373 Hendrik Hakenes and Martin Peitz, Umbrella Branding and the Provision of Quality, December 2004

1374 Sascha O. Becker, Karolina Ekholm, Robert Jäckle and Marc-Andreas Mündler, Location Choice and Employment Decisions: A Comparison of German and Swedish Multinationals, January 2005

1375 Christian Gollier, The Consumption-Based Determinants of the Term Structure of Discount Rates, January 2005

1376 Giovanni Di Bartolomeo, Jacob Engwerda, Joseph Plasmans, Bas van Aarle and Tomasz Michalak, Macroeconomic Stabilization Policies in the EMU: Spillovers, Asymmetries, and Institutions, January 2005 
1377 Luis H. R. Alvarez and Erkki Koskela, Progressive Taxation and Irreversible Investment under Uncertainty, January 2005

1378 Theodore C. Bergstrom and John L. Hartman, Demographics and the Political Sustainability of Pay-as-you-go Social Security, January 2005

1379 Bruno S. Frey and Margit Osterloh, Yes, Managers Should Be Paid Like Bureaucrats, January 2005

1380 Oliver Hülsewig, Eric Mayer and Timo Wollmershäuser, Bank Loan Supply and Monetary Policy Transmission in Germany: An Assessment Based on Matching Impulse Responses, January 2005

1381 Alessandro Balestrino and Umberto Galmarini, On the Redistributive Properties of Presumptive Taxation, January 2005

1382 Christian Gollier, Optimal Illusions and Decisions under Risk, January 2005

1383 Daniel Mejía and Marc St-Pierre, Unequal Opportunities and Human Capital Formation, January 2005

1384 Luis H. R. Alvarez and Erkki Koskela, Optimal Harvesting under Resource Stock and Price Uncertainty, January 2005

1385 Ruslan Lukach, Peter M. Kort and Joseph Plasmans, Optimal R\&D Investment Strategies with Quantity Competition under the Threat of Superior Entry, January 2005

1386 Alfred Greiner, Uwe Koeller and Willi Semmler, Testing Sustainability of German Fiscal Policy. Evidence for the Period 1960 - 2003, January 2005

1387 Gebhard Kirchgässner and Tobias Schulz, Expected Closeness or Mobilisation: Why Do Voters Go to the Polls? Empirical Results for Switzerland, 1981 - 1999, January 2005

1388 Emanuele Bacchiocchi and Alessandro Missale, Managing Debt Stability, January 2005

1389 Assar Lindbeck and Dirk Niepelt, Improving the SGP: Taxes and Delegation rather than Fines, January 2005

1390 James J. Heckman and Dimitriy V. Masterov, Skill Policies for Scotland, January 2005

1391 Emma Galli \& Fabio Padovano, Sustainability and Determinants of Italian Public Deficits before and after Maastricht, January 2005

1392 Angel de la Fuente and Juan Francisco Jimeno, The Private and Fiscal Returns to Schooling and the Effect of Public Policies on Private Incentives to Invest in Education: A General Framework and Some Results for the EU, January 2005

1393 Juan C. Conesa and Carlos Garriga, Optimal Response to a Demographic Shock, January 2005 
1394 Christian Gollier, Optimal Portfolio Management for Individual Pension Plans, February 2005

1395 Ruslan Lukach, Joseph Plasmans and Peter M. Kort, Innovation Strategies in a Competitive Dynamic Setting, February 2005

1396 Gebhard Kirchgässner, (Why) Are Economists Different?, February 2005

1397 Marko Köthenbürger, Panu Poutvaara and Paola Profeta, Why are More Redistributive Social Security Systems Smaller? A Median Voter Approach, February 2005

1398 Gabrielle Demange, Free Choice of Unfunded Systems: A First Assessment, February 2005

1399 Carlos Fonseca Marinheiro, Sustainability of Portuguese Fiscal Policy in Historical Perspective, February 2005

1400 Roel M. W. J. Beetsma and Koen Vermeylen, The Effect of Monetary Unification on Public Debt and its Real Return, February 2005

1401 Frank Asche, Petter Osmundsen and Maria Sandsmark, Is It All Oil?, February 2005

1402 Giacomo Corneo, Media Capture in a Democracy: The Role of Wealth Concentration, February 2005

1403 A. Lans Bovenberg and Thijs Knaap, Ageing, Funded Pensions and the Dutch Economy, February 2005

1404 Thiess Büttner, The Incentive Effect of Fiscal Equalization Transfers on Tax Policy, February 2005

1405 Luisa Fuster, Ayşe İmrohoroğlu and Selahattin İmrohoroğlu, Personal Security Accounts and Mandatory Annuitization in a Dynastic Framework, February 2005

1406 Peter Claeys, Policy Mix and Debt Sustainability: Evidence from Fiscal Policy Rules, February 2005

1407 James M. Malcomson, Supplier Discretion over Provision: Theory and an Application to Medical Care, February 2005

1408 Thorvaldur Gylfason, Interview with Assar Lindbeck, February 2005

1409 Christian Gollier, Some Aspects of the Economics of Catastrophe Risk Insurance, February 2005

1410 Gebhard Kirchgässner, The Weak Rationality Principle in Economics, February 2005

1411 Carlos José Fonseca Marinheiro, Has the Stability and Growth Pact Stabilised? Evidence from a Panel of 12 European Countries and Some Implications for the Reform of the Pact, February 2005 
1412 Petter Osmundsen, Frank Asche, Bård Misund and Klaus Mohn, Valuation of International Oil Companies -The RoACE Era, February 2005

1413 Gil S. Epstein and Shmuel Nitzan, Lobbying and Compromise, February 2005

1414 Marcel F. M. Canoy, Jan C. van Ours and Frederick van der Ploeg, The Economics of Books, February 2005

1415 Eric A. Hanushek and Ludger Wößmann, Does Educational Tracking Affect Performance and Inequality? Differences-in-Differences Evidence across Countries, February 2005

1416 George Kapetanios and M. Hashem Pesaran, Alternative Approaches to Estimation and Inference in Large Multifactor Panels: Small Sample Results with an Application to Modelling of Asset Returns, February 2005

1417 Samuel Mühlemann, Jürg Schweri, Rainer Winkelmann and Stefan C. Wolter, A Structural Model of Demand for Apprentices. February 2005

1418 Giorgio Brunello and Lorenzo Rocco, Educational Standards in Private and Public Schools, February 2005

1419 Alex Bryson, Lorenzo Cappellari and Claudio Lucifora, Why so Unhappy? The Effects of Unionisation on Job Satisfaction, March 2005

1420 Annalisa Luporini, Relative Performance Evaluation in a Multi-Plant Firm, March 2005

1421 Giorgio Bellettini and Carlotta Berti Ceroni, When the Union Hurts the Workers: A Positive Analysis of Immigration Policy, March 2005

1422 Pieter Gautier, Michael Svarer and Coen Teulings, Marriage and the City, March 2005

1423 Ingrid Ott and Stephen J. Turnovsky, Excludable and Non-Excludable Public Inputs: Consequences for Economic Growth, March 2005

1424 Frederick van der Ploeg, Back to Keynes?, March 2005

1425 Stephane Dees, Filippo di Mauro, M. Hashem Pesaran and L. Vanessa Smith, Exploring the International Linkages of the Euro Area: a Global VAR Analysis, March 2005

1426 Hans Pitlik, Friedrich Schneider and Harald Strotmann, Legislative Malapportionment and the Politicization of Germany's Intergovernmental Transfer System, March 2005

1427 Konstantinos Angelopoulos and Apostolis Philippopoulos, The Role of Government in Anti-Social Redistributive Activities, March 2005 